جيوبولتيك قالنة المعلومات ولاتصالاتفي الرلن العري

- التحيلت والفرص المتلحة ولائمان -

الأستال الكتورمحمد أزهر اللسمك

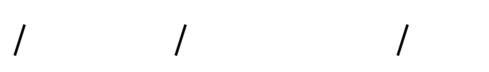

جلمعة الموصل
الكتور أحمد حامد ألعبيى

لأستاذ مساءد/ قسم الجغرافية/لكلية التربية/ لهمية

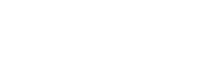

مستخلص البهث

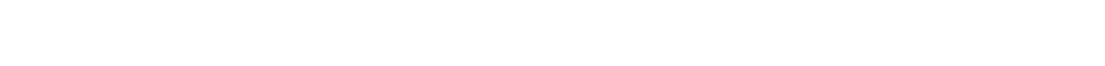

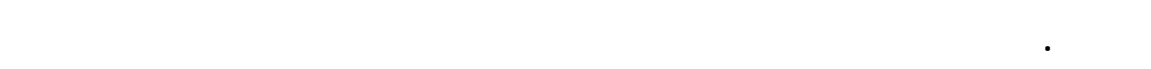

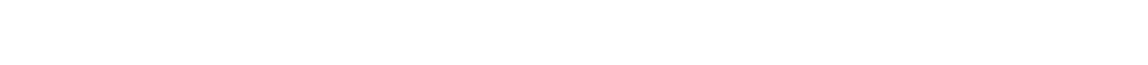

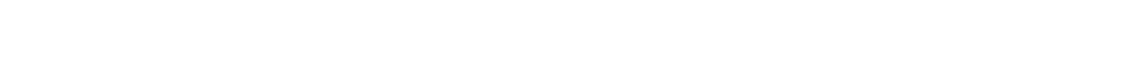

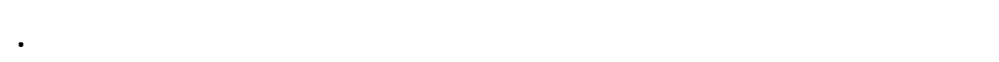
وقد تضمن البهث درلسة القلال التالية: أولالا: وفع قفلة المعلوملت ولانصلات.

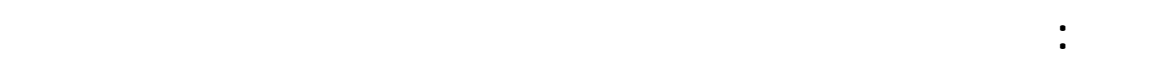

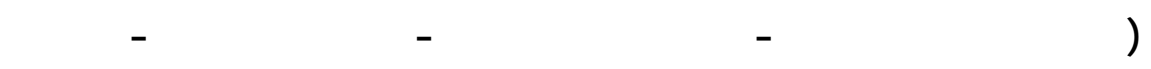

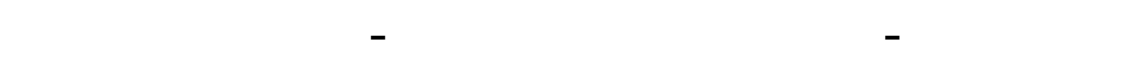

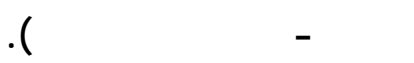

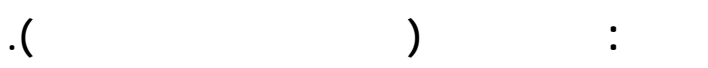

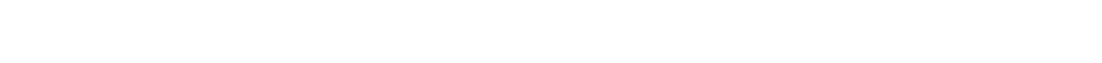

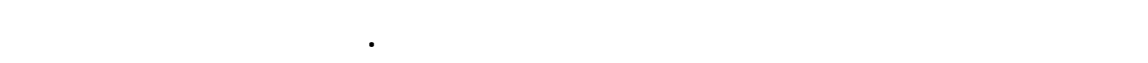

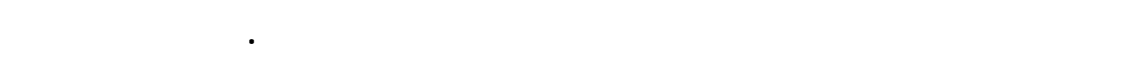

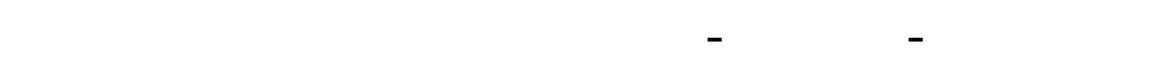
الثورة المعلوملنية وعصر العولمة. 


\section{هف البهث ومنهجه:}

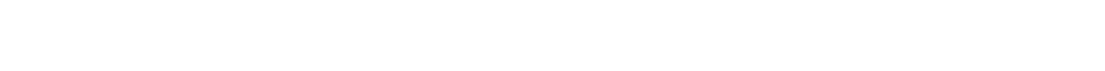

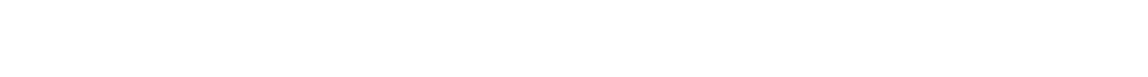

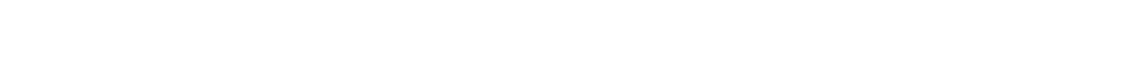

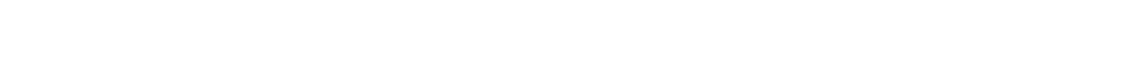

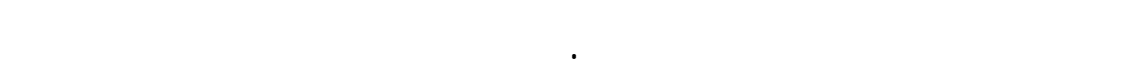

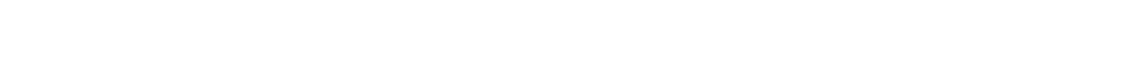
وللسيلي بسواء.

صحبح أن هنك عناصر عدية تحدد مفهوم القوة الشلملة ,طبقاء

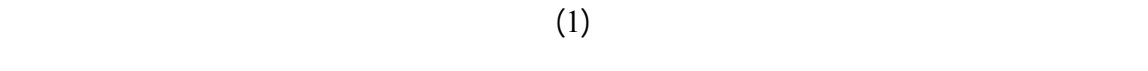

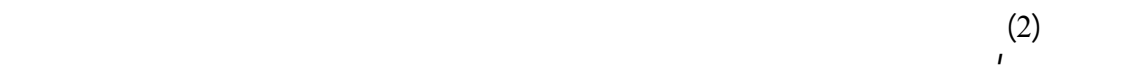
والتحليل طقا لمناهج تحليل القوة في الجغرافيا للسيلسية.

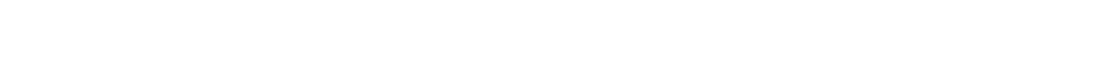

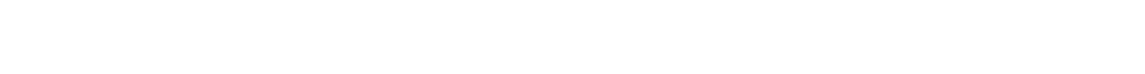

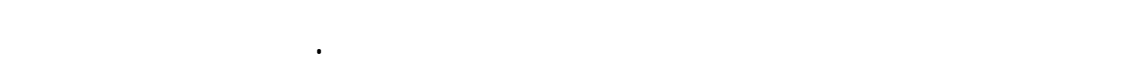

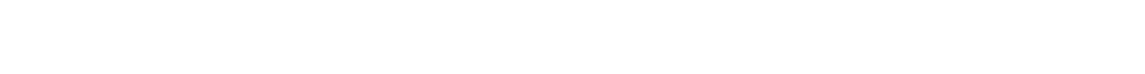

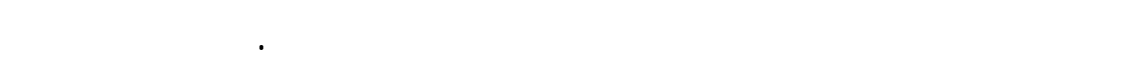

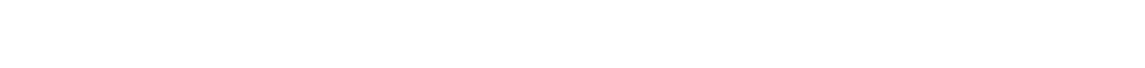
القل من التخصص. من هنا بدا الاهتملم بدرلسة مشكلة هذا البحث التي تتنخص في غيلب

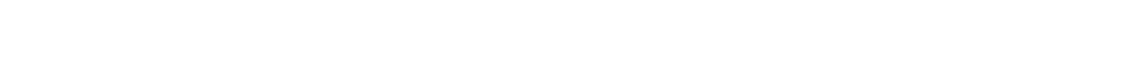

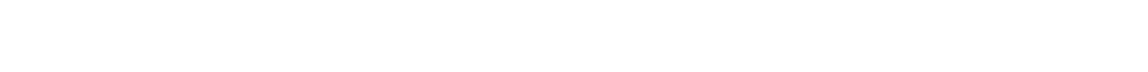

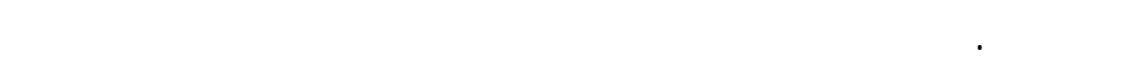


الجوالب في لستخداملت الحلسبت الإلكترونية مرورا بأجهزة الاتصل

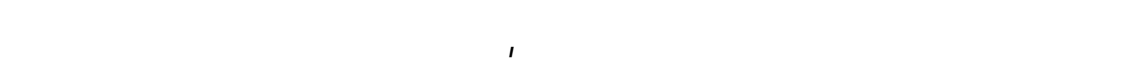

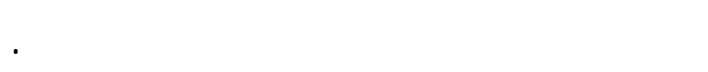

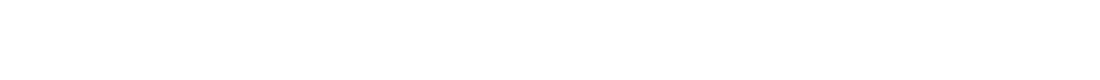

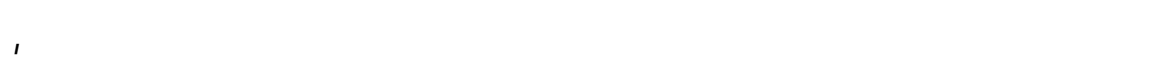

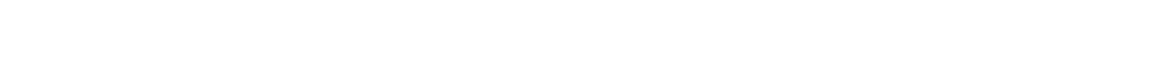

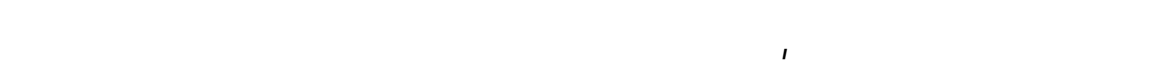
التحديت المختلفة.

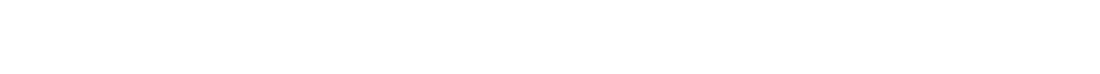

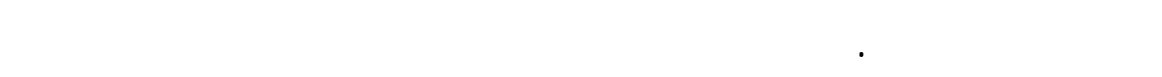

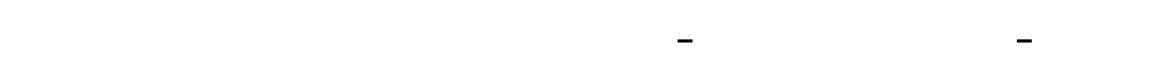

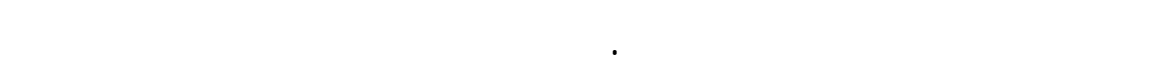
درلسة الموضوعلت التالية: أولا: واقع نقانة المعلوملت والاتتصالات في الوطن العربي.

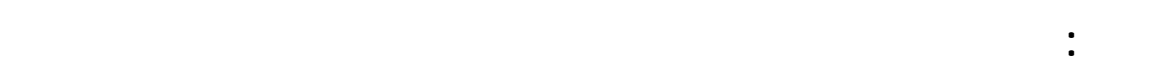

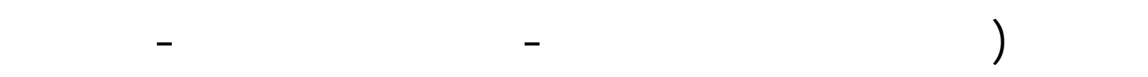

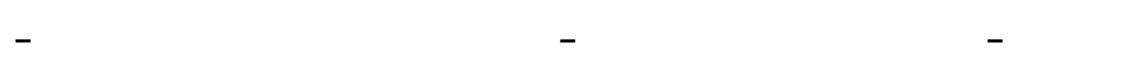
دليل النتشار الاختراعت القديمة - المهارات البشرية - التبعية القنية). شالثا: الاستتنجلت (التحديت والفرص المتار المتلحة).

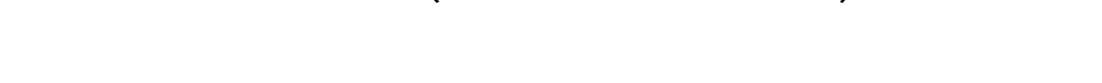

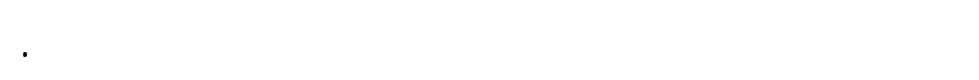

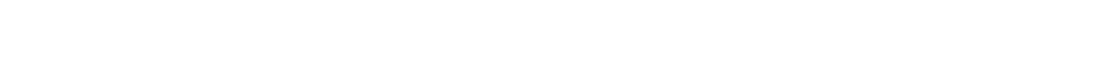

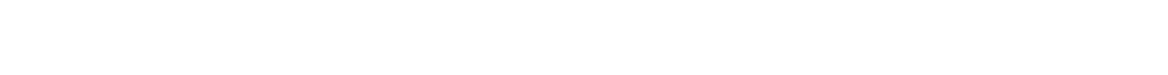

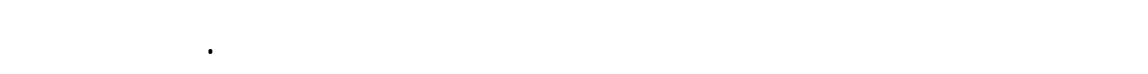


العل الجاد من لجل 》نهضة الأمة《 في توفيرشروط الحداثة للمجتمع

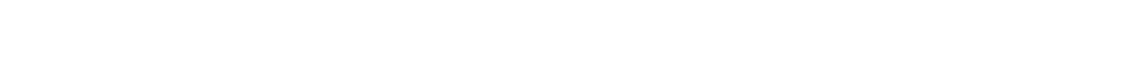

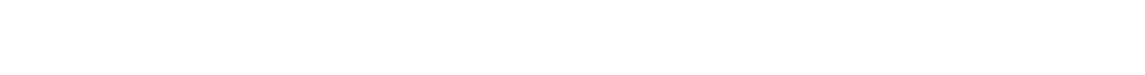

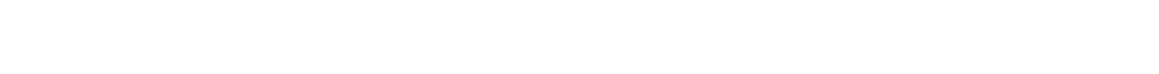
وتعزيز الاستقلال الميلسي بالتالي .

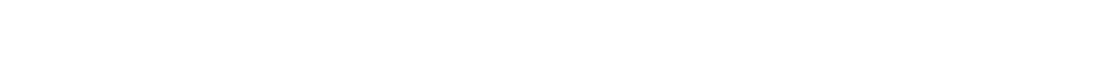

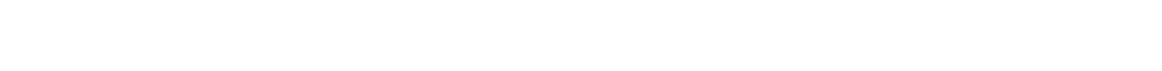

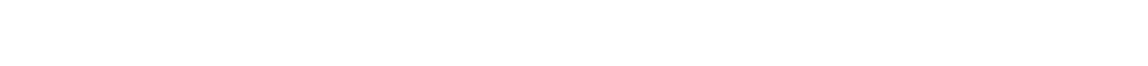
والعلاقلت الأولية. فان وفقنا فهذا غاية المن وبخلافه فهو قدرنا ومن الم التوفق.

\section{أولا : ولع قالنة المعالومات والاتصلات في الطان العري}

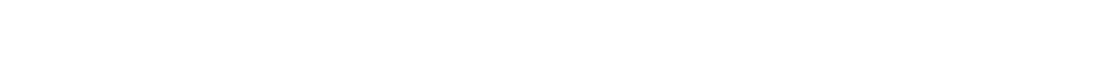

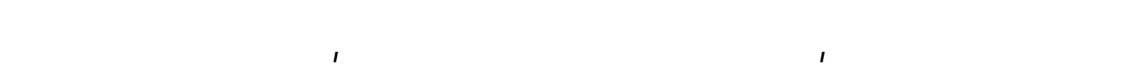

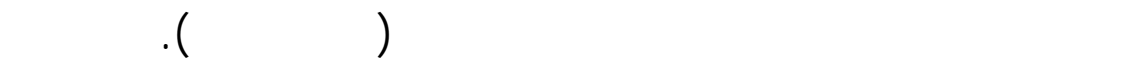

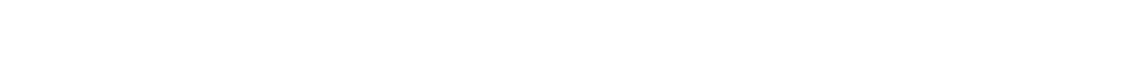

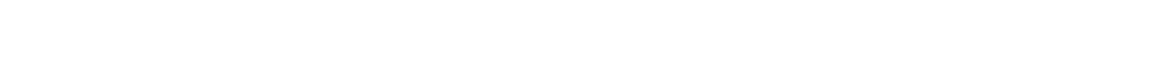

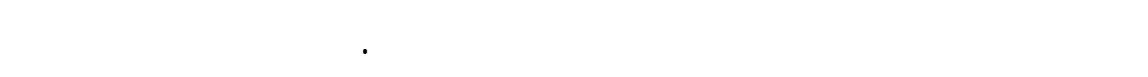

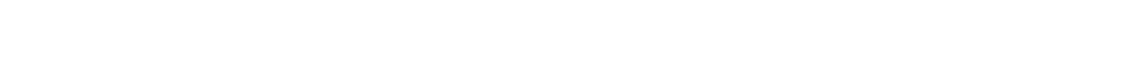

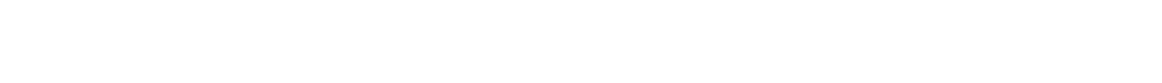

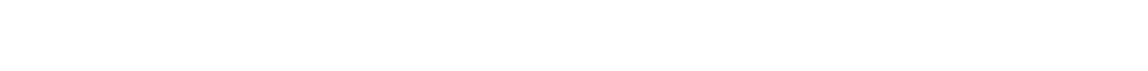
النعكلساته المختلفة علىسترالتيجية الوحدات للسيلسية المتمثلة (بالرفاهية).

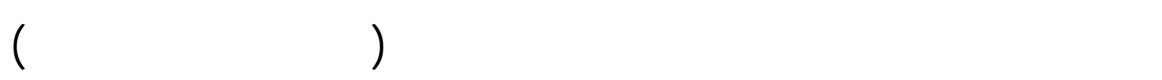


والحكوملت الإلكترونية مجسة بذلك دور هذه العناصر في الإدارة الحيثة

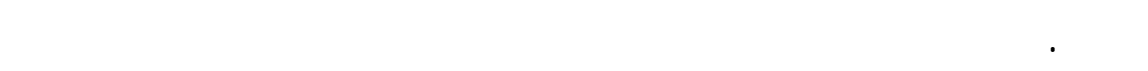

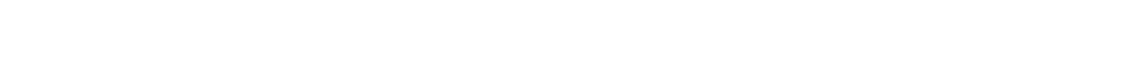

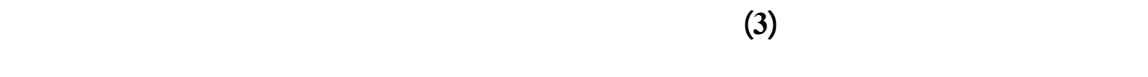

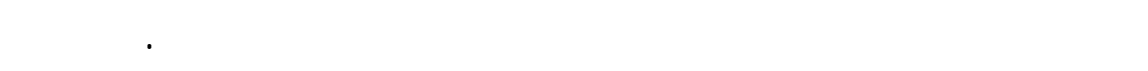

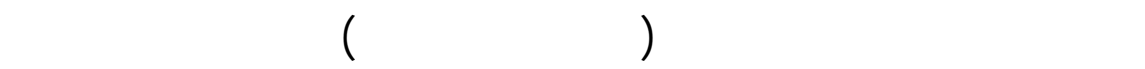

$$
\text { الجداول (1،2،2، ومنها نستنتج : }
$$

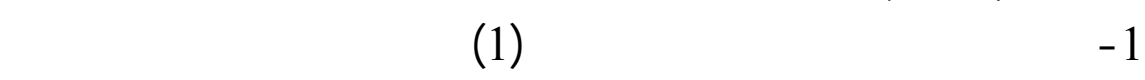

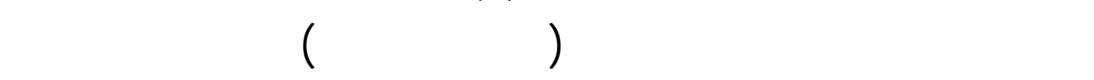

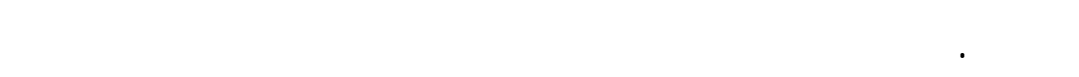

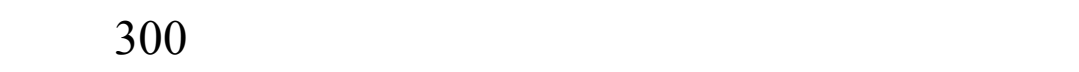

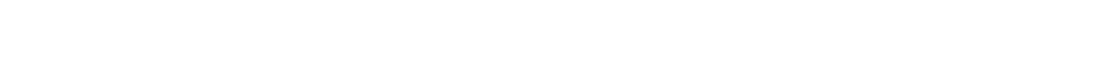
الناتج المحلي الإجمالي وقرلبة خهس ظظرائه في دول مظمة الإيهة التعاون

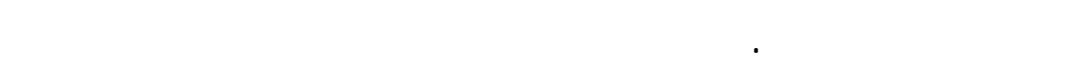

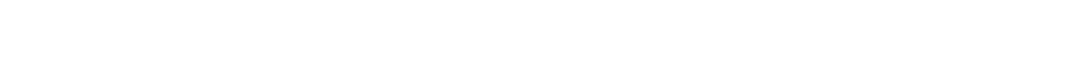

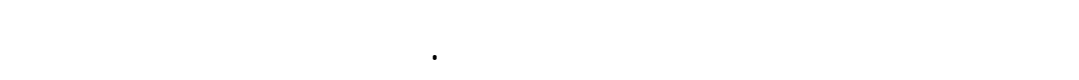

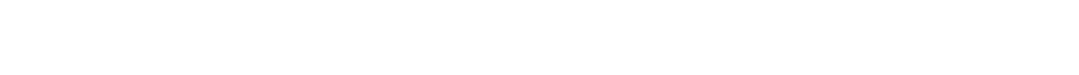

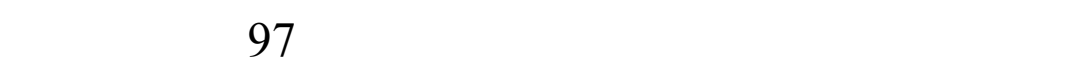

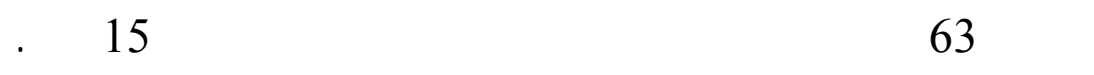

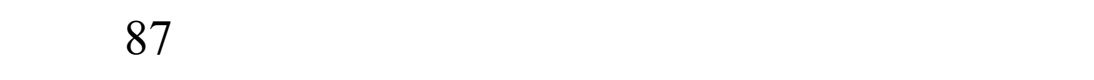

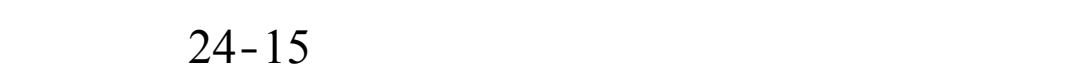

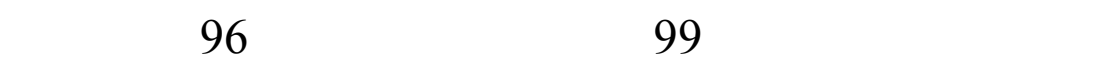

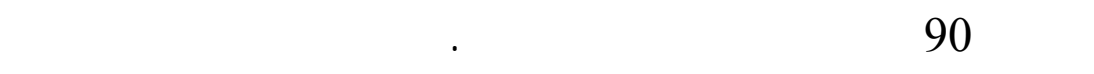

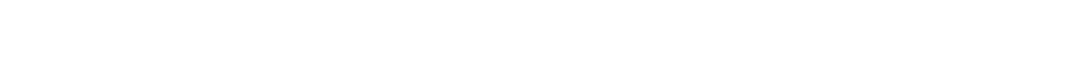

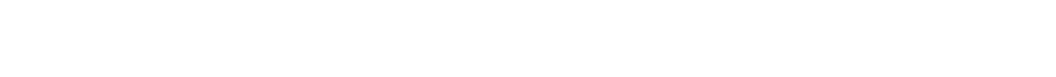


جدط (1)

توزيع المؤشرك تكوين رلأس المل البشريف الطان العري وألهده

مقارنة أخرى البنري

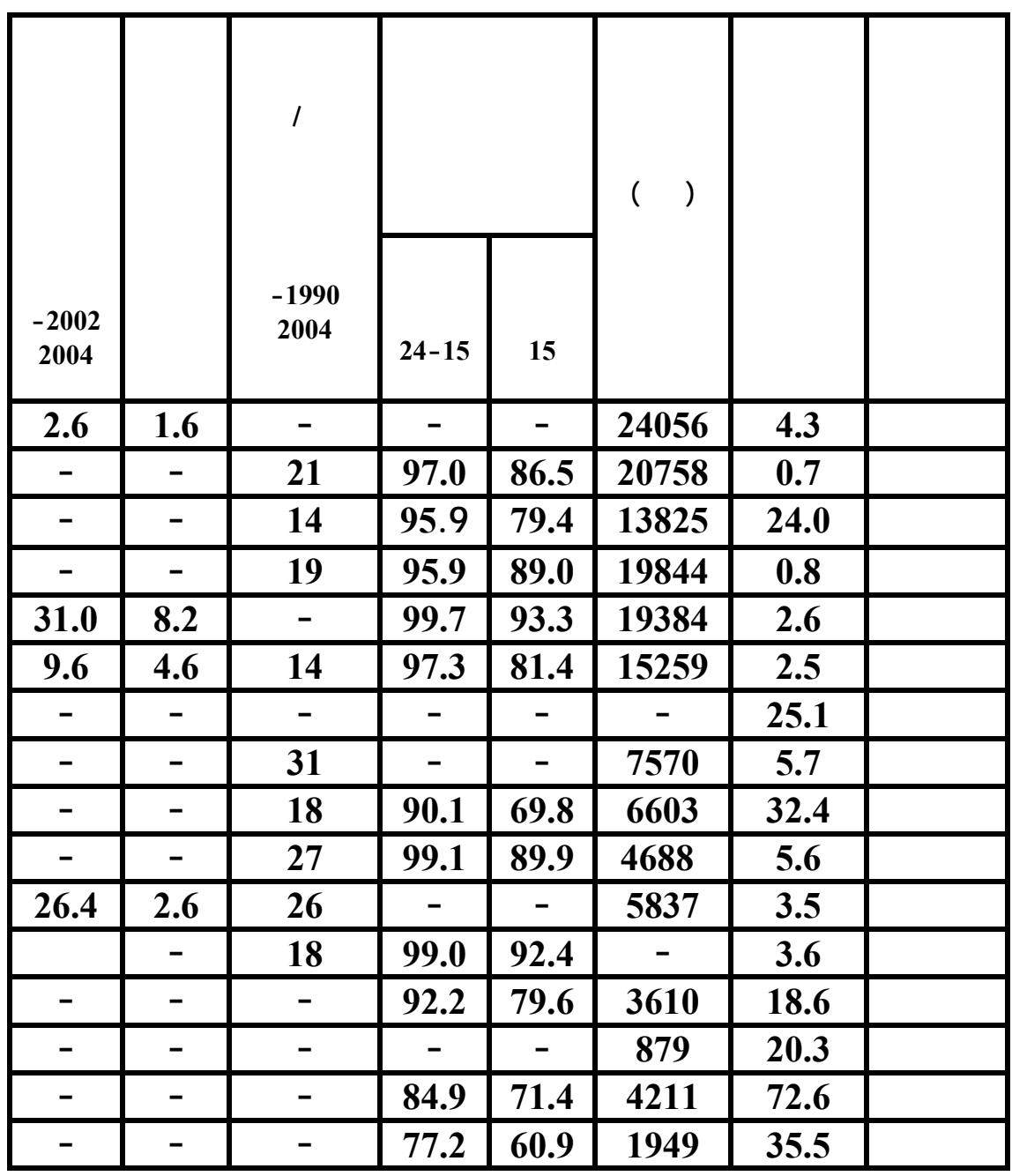




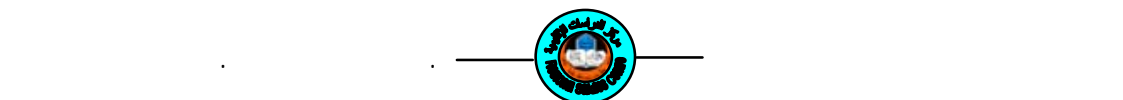

\begin{tabular}{|c|c|c|c|c|c|c|c|}
\hline الإلعلى & الإفلى & مالعالم العليم & ي الكإلملة & مبالفرا: & الالنردمن الإلتج & بالملالينن & المط \\
\hline $\begin{array}{c}\text { العمليم } 2002 \\
2004\end{array}$ & الإجمالّ & 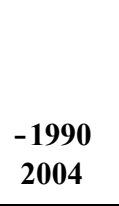 & $\begin{array}{c}\text { اللشبل } \\
\text { عمد } 24 \\
-15 \\
24\end{array}$ & 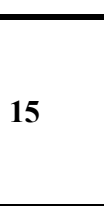 & & & \\
\hline 19.4 & 8.1 & - & 94.3 & 74.3 & 7768 & 10.0 & توضس \\
\hline 14.7 & 6.3 & 18 & 70.5 & 52.3 & 4309 & 31.0 & المغرب \\
\hline 4.3 & 3.4 & 10 & 61.3 & 51.2 & 1940 & 3.0 & موربتلنيا \\
\hline - & 3.9 & 11 & - & - & 1943 & 0.8 & \\
\hline$=$ & 6.1 & 22 & - & $\overline{-}$ & 1993 & 0.8 & جيبوقي \\
\hline - & 5.9 & 20 & - & - & 39676 & 295.4 & المتحليت \\
\hline 17.1 & 7.3 & 30 & 99.8 & 97.1 & 24382 & 6.6 & إسراكئل \\
\hline 14.5 & 4.8 & 38 & - & 77.0 & 7525 & 68.8 & إيرلن \\
\hline- & 3.6 & $=$ & 95.6 & 87.4 & 7753 & 72.2 & تركيا \\
\hline - & - & - & - & - & 27571 & 6389.2 & $\begin{array}{c}\text { مظامة } \\
\text { OECD }\end{array}$ \\
\hline
\end{tabular}

المصدر: الأم المتحة: قربر التنمية البث ـربة لد لم 2006، نيوب ورك، بدلال ـة البيلنت في جدالر 1، 5، 1، 11، 12، 14.

تهظى بأعلى النس من الأففاق على التعليم (7.3\%) من الناتج المحلي الإجمالي, مما يشير إله الفهم المدرك لدور التعلي م في ظور قطاعلت الإنتاج والخدمات في جهم الدولة . 
عله أنه من الموضوعية أن نشير إلى إن الدول العربية النطية

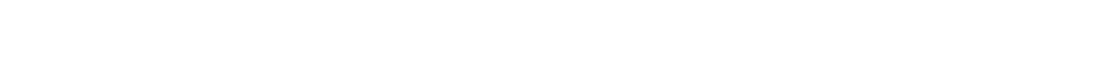

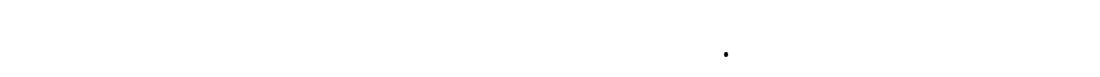

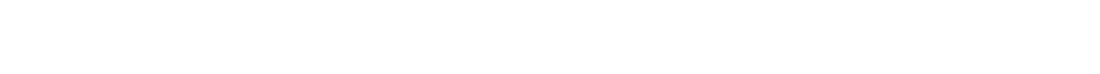

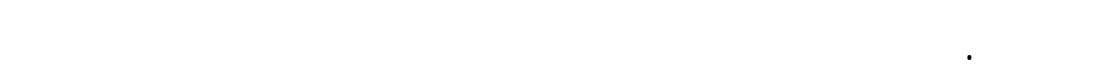

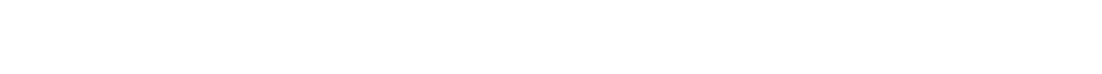

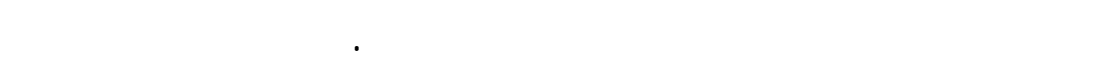

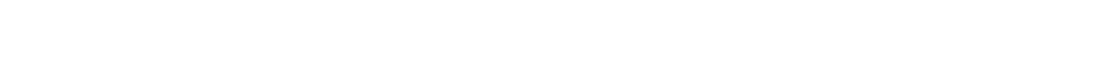

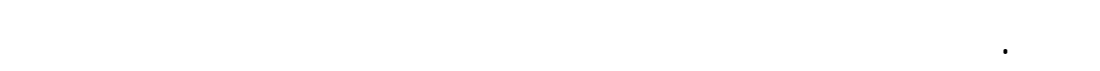
الأمارات نحو (24) ألف دولار وقرابة (20) أف دولار في كل من البحرين

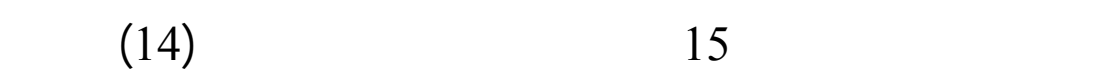

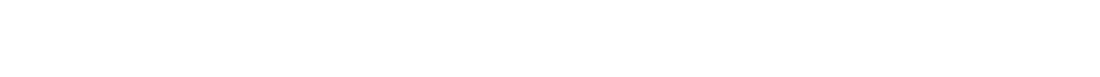

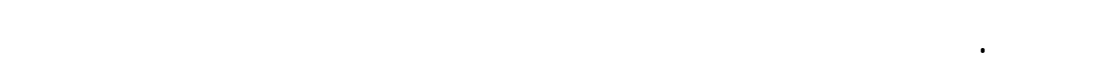

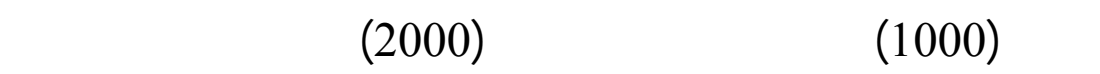

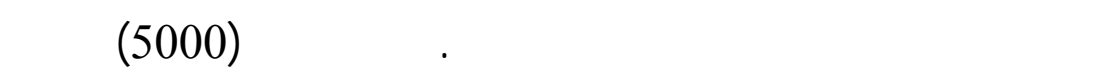

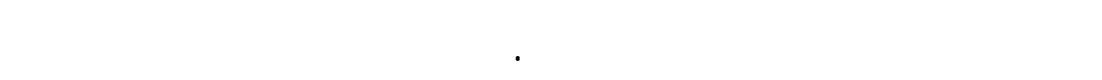

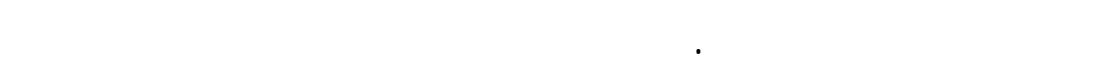

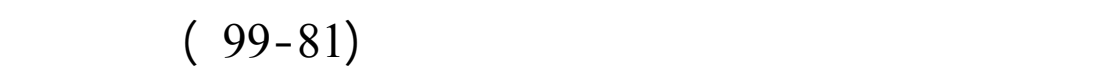

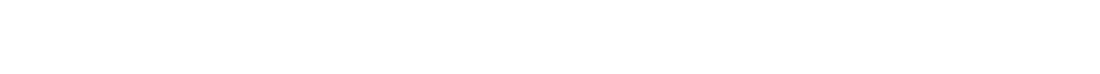

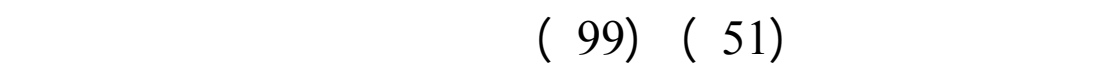

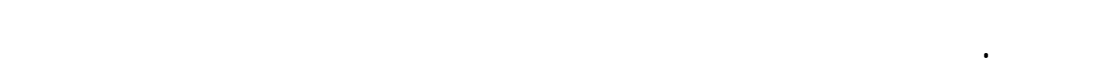

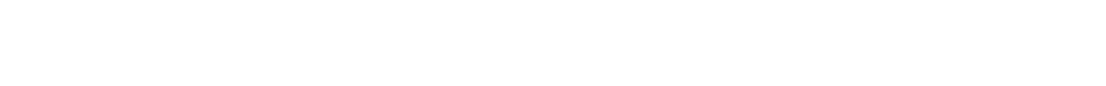




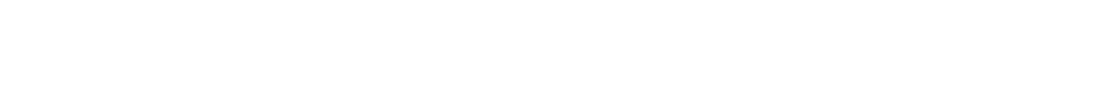

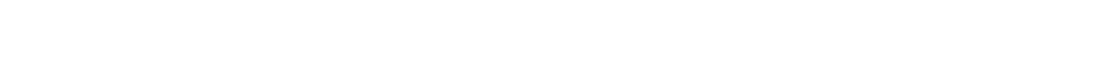

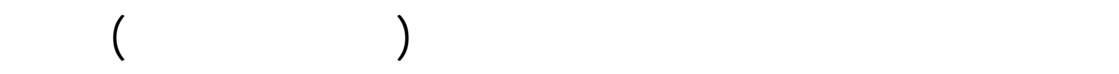

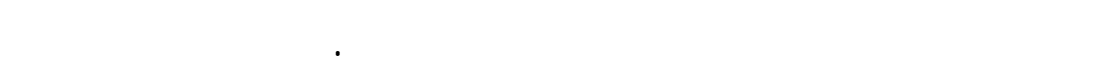

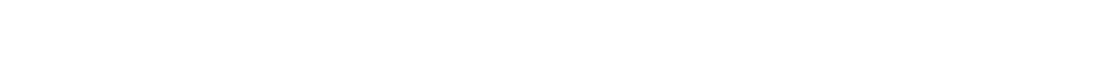
مستويت التعليم التي بلغت زهاء (19.4٪).

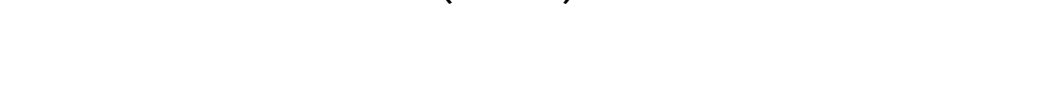

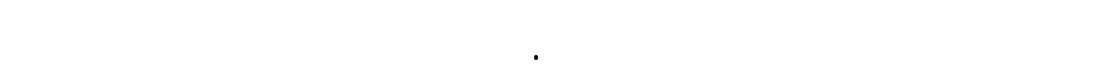

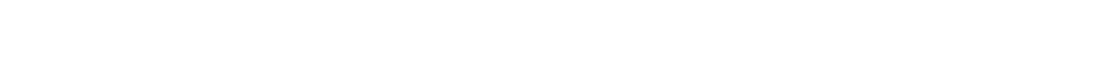

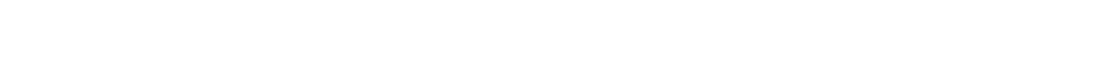

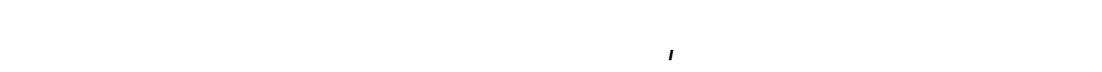
دولبا وإقليمبا وقومبا ال

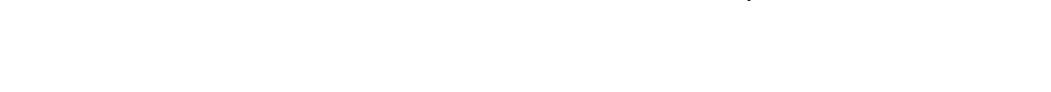

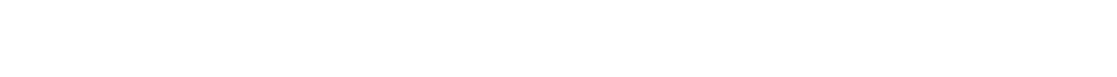

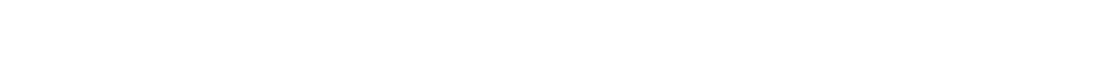

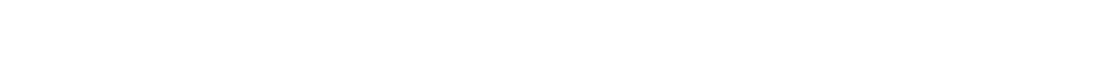

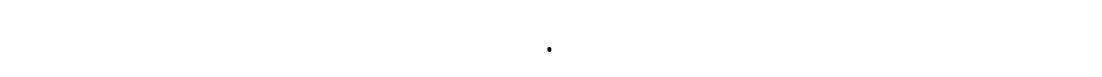
تندي واضضح لدول عربية نطظية في هذا المجل كليبيا والجزائر.

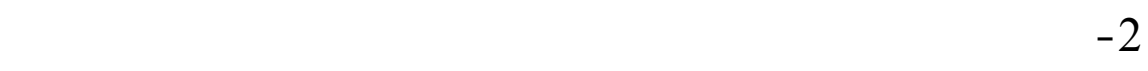

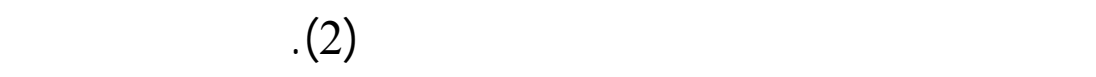

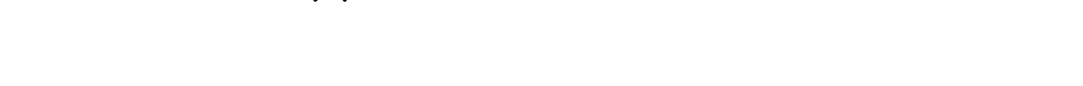

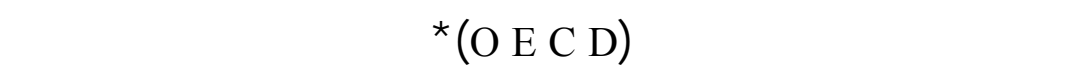

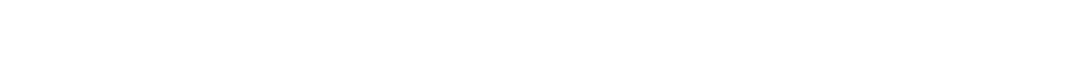
في إعرائيل. في حين تتضاعف هذو النه النبة في الولايلت المتحة 
الأمريكية إذ تصل إلى ثمانية أمثل ظارائها في الوطن العربي.

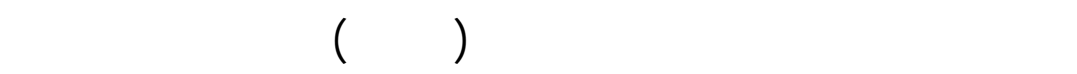

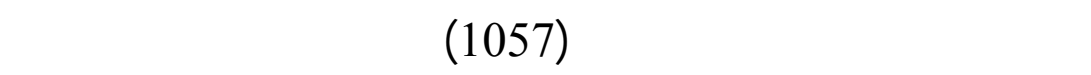

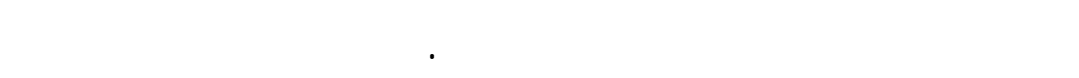

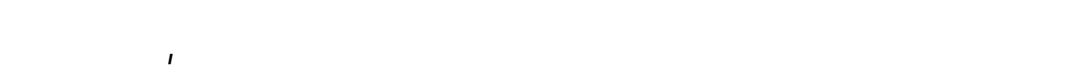

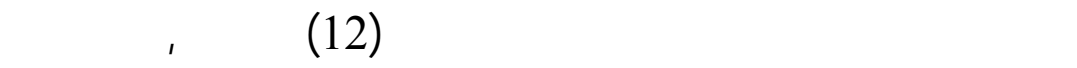

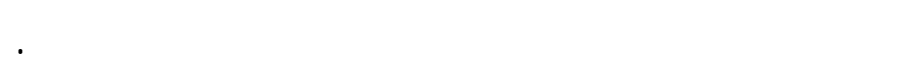

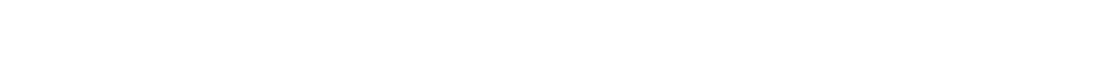

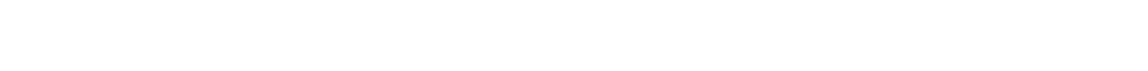

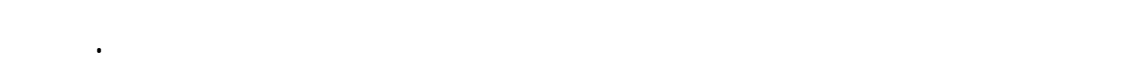

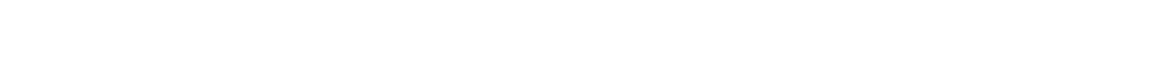

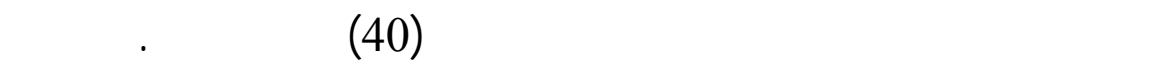

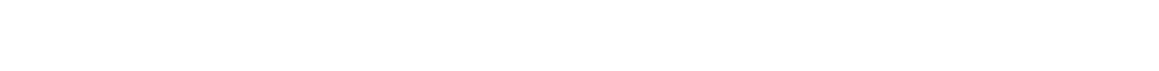
التظطي والبرمجة والإدارة للك مرافق الحيلة إنتلجاه وخدملت أدركنا

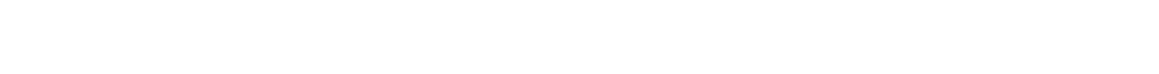

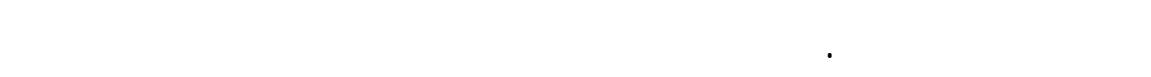

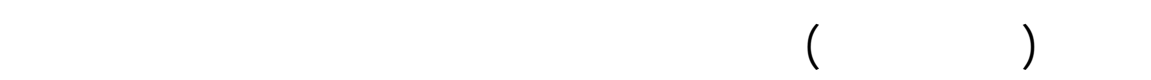

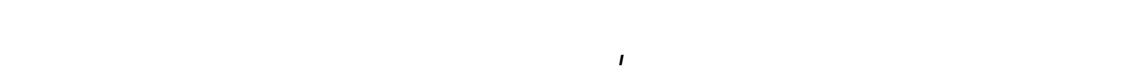

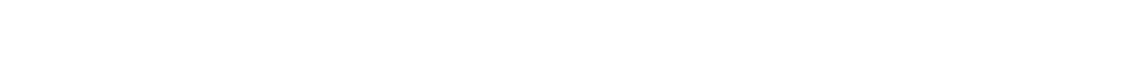




\section{جنط (2)}

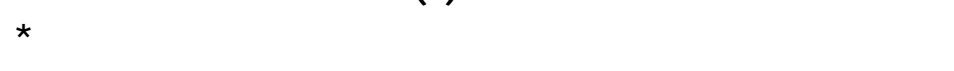

\begin{tabular}{|c|c|c|c|c|c|c|}
\hline \multirow{2}{*}{ 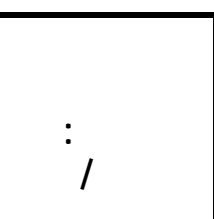 } & \multirow[t]{2}{*}{ الحلنويةية } & الحلسبلت & طشستخمو & الخهولفية & الرهلفي & \multirow[t]{2}{*}{ الدط } \\
\hline & & \multicolumn{4}{|c|}{ Jل 1000 نسمة } & \\
\hline 15.878 & 39655 & 125 & 321 & 853 & 275 & الأمارك \\
\hline 11.274 & 1121 & 140 & 213 & 908 & 268 & الجحرين \\
\hline 6.749 & 5433 & 57 & 66 & 383 & 154 & اللسعونية \\
\hline 19.347 & 31 & 136 & 212 & 631 & 246 & قار \\
\hline 16.379 & 3360 & 121 & 244 & 813 & 202 & الكويت \\
\hline 3.817 & 714 & 26 & 97 & 318 & 95 & عملن \\
\hline- & - & - & - & $=$ & - & العرق \\
\hline 3.347 & - & - & 36 & - & - & ليبيا \\
\hline 929 & $=$ & - & 26 & 145 & 71 & الجزئر \\
\hline 1.524 & 907 & 14 & 110 & 293 & 113 & الأرن \\
\hline 2.829 & 5611 & 46 & 169 & 251 & 178 & لبنلن \\
\hline- & $=$ & - & 46 & 278 & 102 & فلملني \\
\hline 1.683 & $=$ & 14 & 43 & 126 & 143 & عسوربا \\
\hline 212 & 53 & 2 & 9 & 53 & 39 & اليمن \\
\hline 1.340 & 2848 & 12 & 54 & 105 & 130 & مصر \\
\hline 101 & $=$ & - & 32 & 30 & 29 & اللسودلن \\
\hline 1.200 & - & - & 84 & 359 & 121 & تونس \\
\hline 649 & - & - & 117 & 313 & 44 & المغرب \\
\hline 60 & - & - & 5 & 175 & - & موربتلنيا \\
\hline
\end{tabular}


درلسلت إقليمية 5 (11) مركز الدرلست الإقليمية

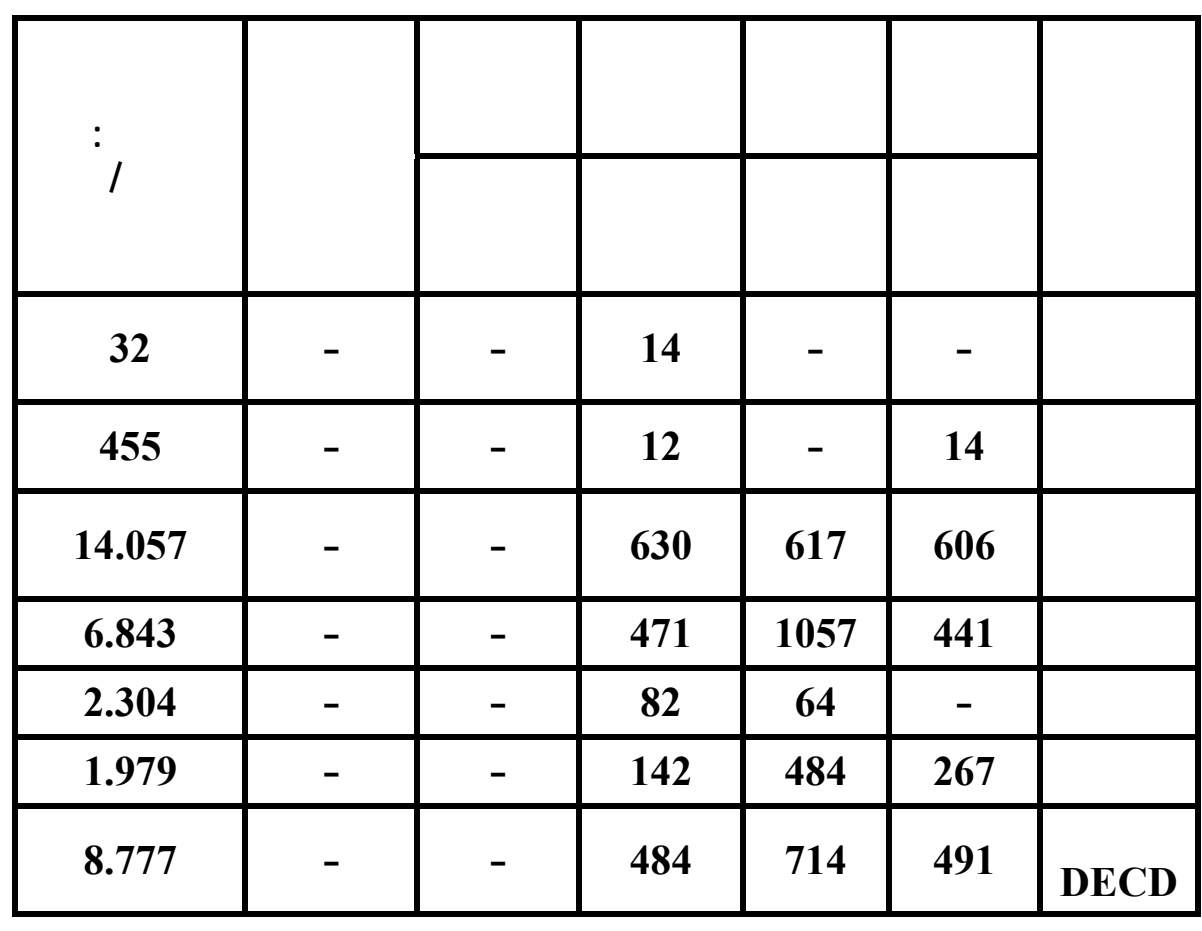

على البلحثن بالاعتماد على :

1 - الأم المتحة : قفربر التنمية البشربة للم 2006، نيوبورك 2006. بدلالة البيلنت في ج دالل

$$
21 \text { و } 13
$$

2 - الاجنة الاغتصاية ولاجتماعية لغري آسيا. طلبق تكنولوجيلت المعلوملت ولانصالات المقمة

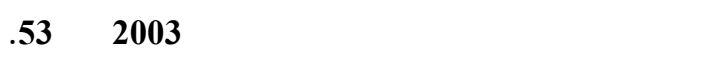

وبالظر إلى البيانت الخاص ـة ء ن عد عدد الحلسب الت والمواقع

الحلسوبية الوطنية تألكدملامح الصورة المشار إليها آلفا.

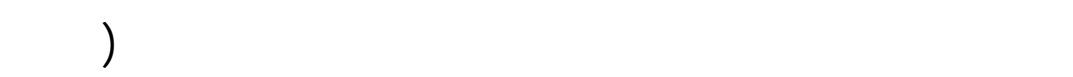

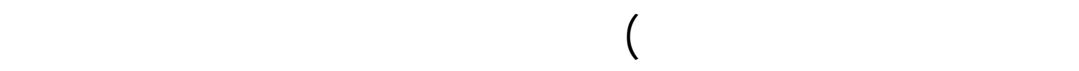

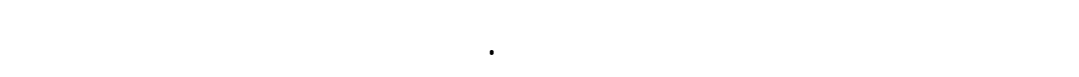
والكويت وقطر وللسعوية أمثلة حية في هذا المجل. وبالمقابل فان المالن 
هنك دولا عربية لانظية محدودة الموارد ولكنها تتمتع بأظمة

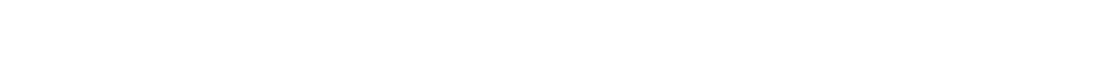

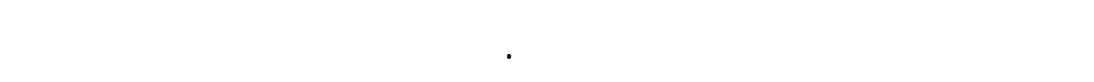
بما ذهبنا إليه في النطة اللسابقة .

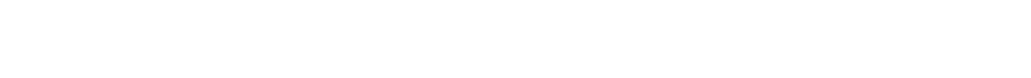

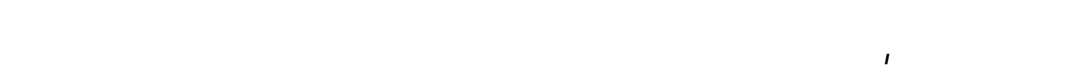

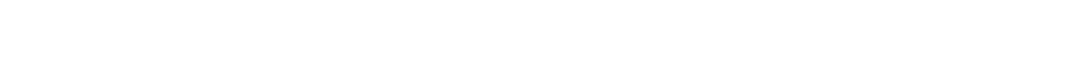

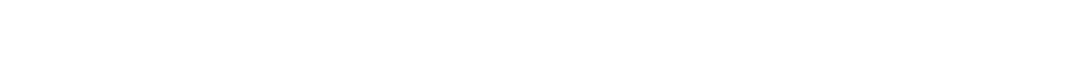
قطر والكويت والإمارات والبحرين.

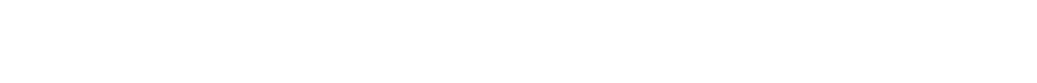

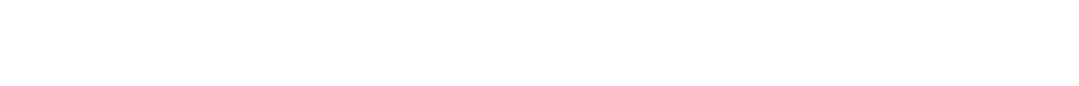

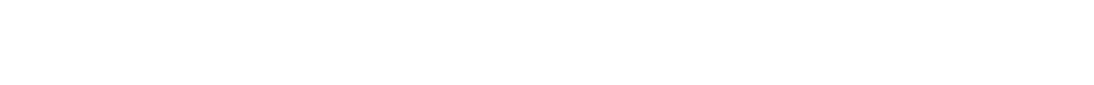

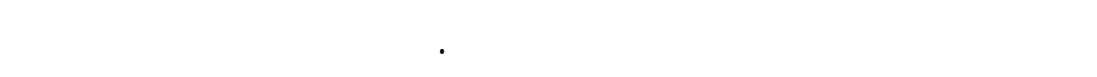

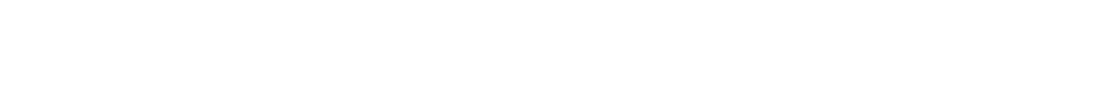

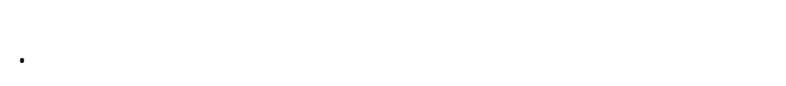

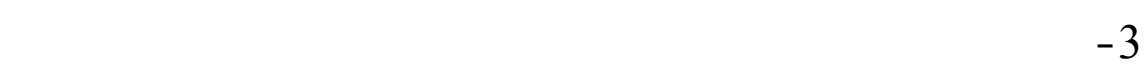

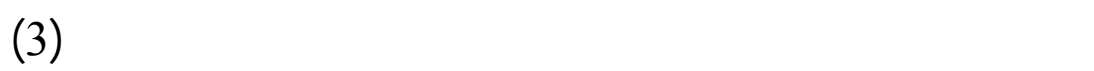

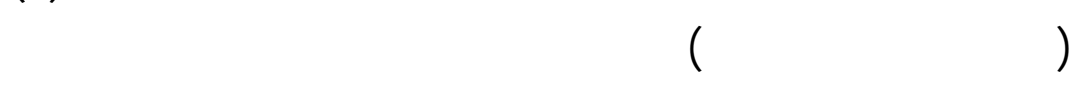

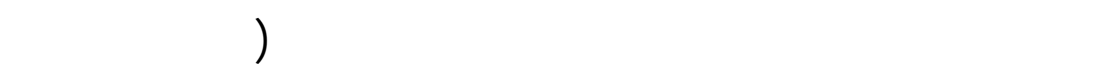

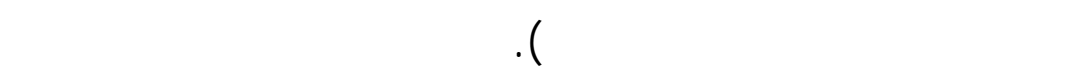

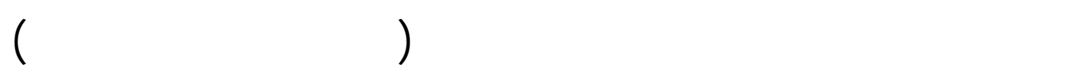

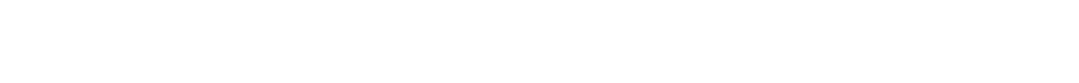

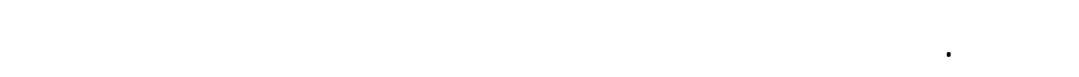


الموارد الإتخدلم الأنسب بـ لـ ببل -وغ حالة التوازن بين لستخداملت الموارد والبيئت المختلفة ذلك مانعبر عنه (بالتنمية المستدالمة).

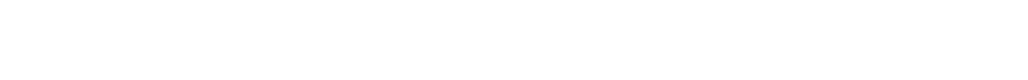

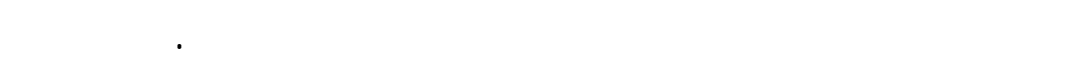

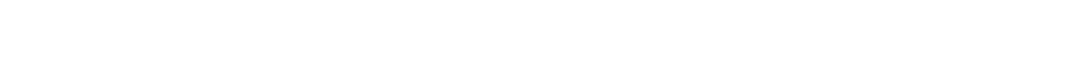

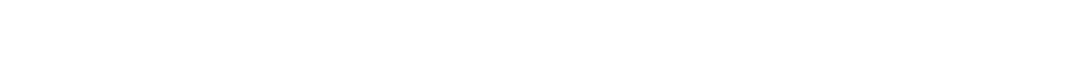

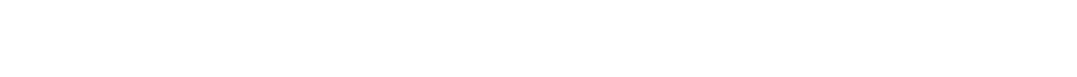
الدول العربية في هذا المجل.

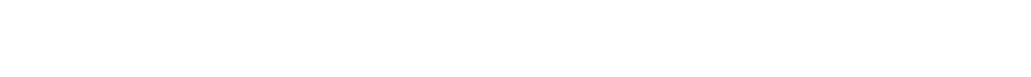
العربي والأهداف المقارنة في هذا البهث.

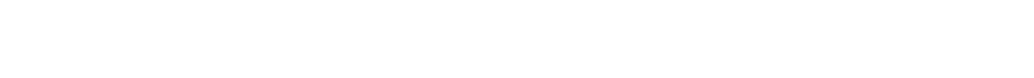

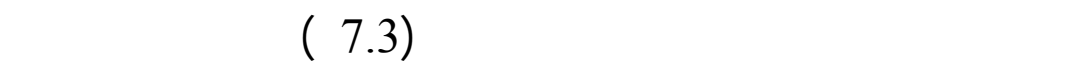

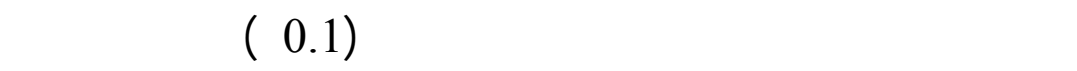

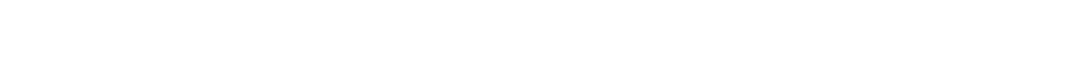

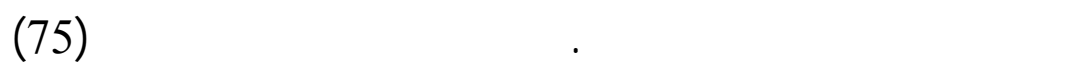

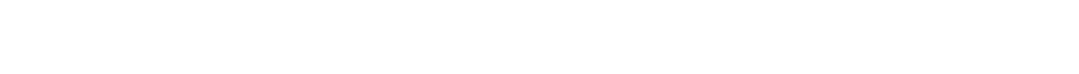

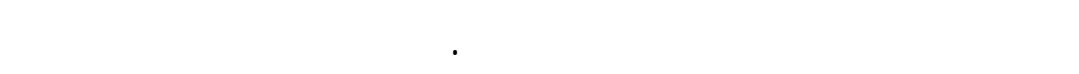

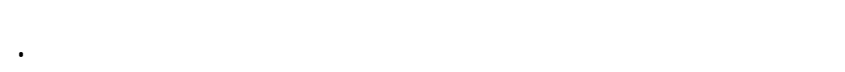

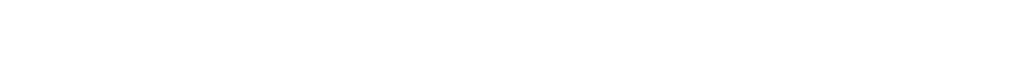

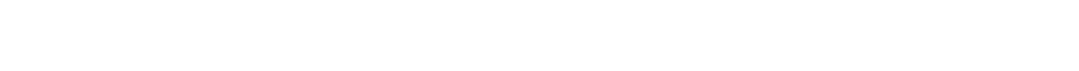

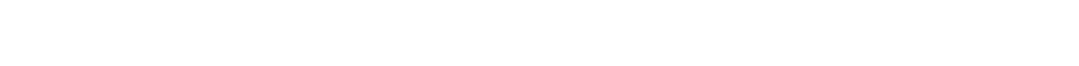

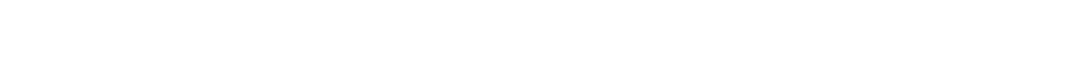
بناء قاعة تكلل تنمية الكوادر العلمية وبيئة خص بة لنة لنم -و بـ -راءات 
الاختراع وحصد ثمار الإففاق على الأبحك. ولن يقم ذلك إلا بلثاعة

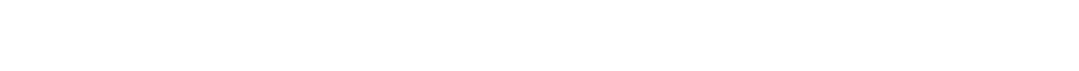

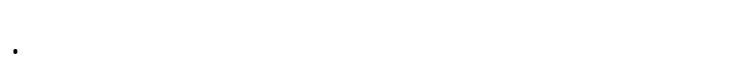

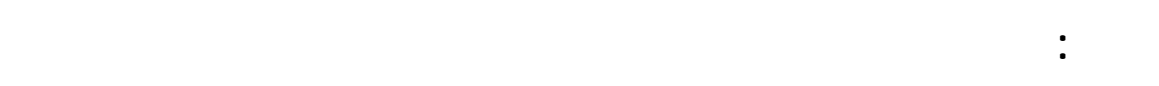 العري:}

بغية الكثف عن واقع ققانة المعلوملت والاتصالات في الوطن العربي العبي

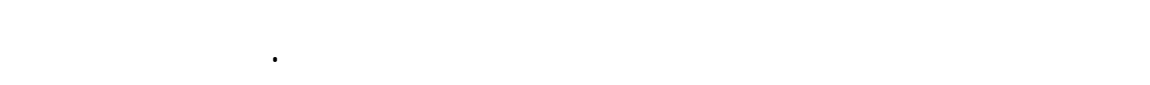

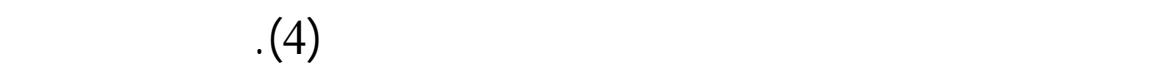

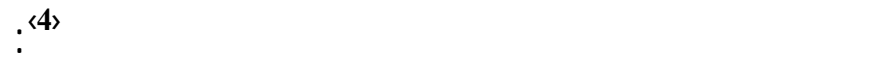

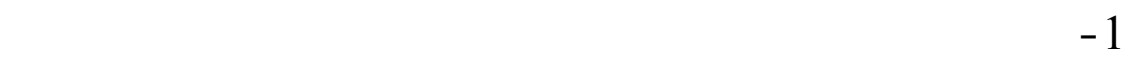

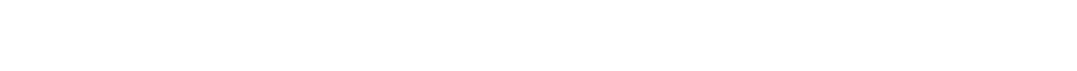
الحيث لذا فان لهما أهميةستراتيجية.

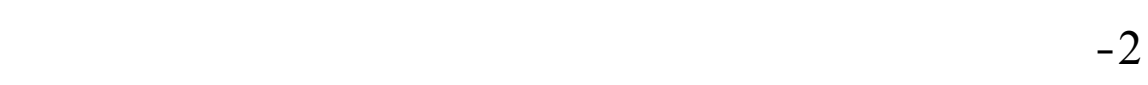
محكومسافا بمسقبل مقرر, والنشطلت في العلم والنقانة لاتحدث في

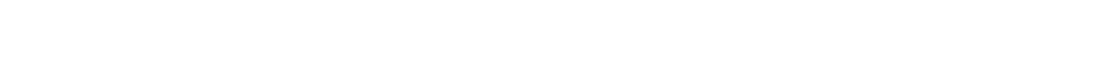

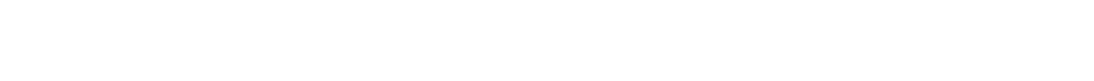
القلف فة اللسيلسية للسائية. 
درلست إقليمية 5 (11) مركز الدرلسلت الإقليمية

(3) جدط

توزع مؤشرات البهث الهامي المان العري وأهدل

* مقارية أخرى

\begin{tabular}{|c|c|c|c|c|c|}
\hline 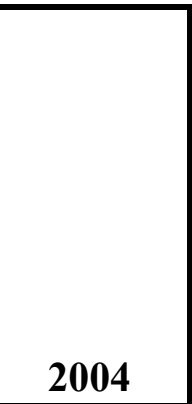 & 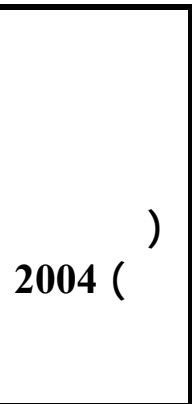 & 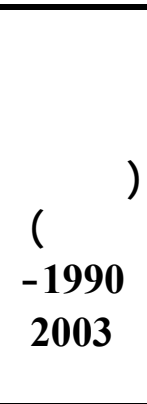 & 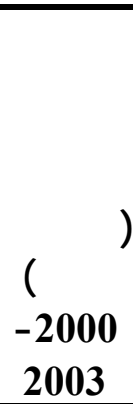 & 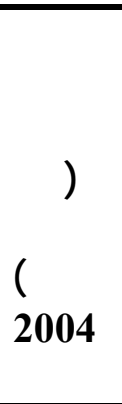 & الدط \\
\hline - & - & - & - & - & لأمارت \\
\hline 3 & - & - & - & - & البحرين \\
\hline 2 & صفر & - & - & - & السجووية \\
\hline 1 & $\overline{-}$ & $\overline{-}$ & $\overline{-}$ & $\overline{-}$ & قلر \\
\hline- & صفر & 69 & 0.2 & $=$ & الكوبت \\
\hline 1 & - & - & - & - & عملن \\
\hline- & - & - & - & - & العرق \\
\hline$\overline{-}$ & صفر & 361 & $\overline{-}$ & $\overline{-}$ & ليبيا \\
\hline 1 & - & - & - & 1 & الجزائر \\
\hline 5 & - & 1.927 & $=$ & $=$ & الررن \\
\hline 2 & $=$ & $=$ & $=$ & $=$ & لبنل \\
\hline- & - & $=$ & - & - & فلمطين \\
\hline 1 & - & 29 & $\overline{-}$ & $\overline{-}$ & سوريا \\
\hline 13 & - & - & - & - & اليهن \\
\hline 1 & 1.4 & - & 0.2 & $=$ & ر \\
\hline$=$ & - & 263 & 0.3 & $=$ & السودلن \\
\hline 5 & 1.8 & 1.013 & 0.6 & - & توضس \\
\hline 10 & 0.5 & 782 & 0.6 & $\overline{-}$ & المغرب \\
\hline
\end{tabular}




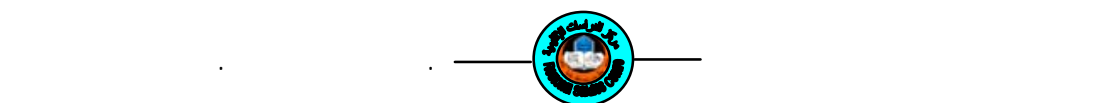

\begin{tabular}{|c|c|c|c|c|c|}
\hline 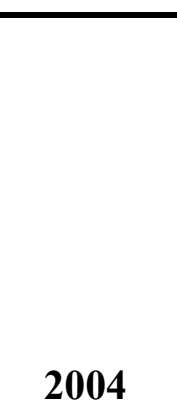 & فرقائوضلت & 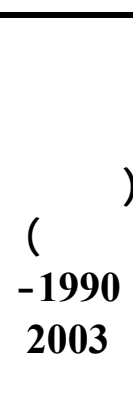 & 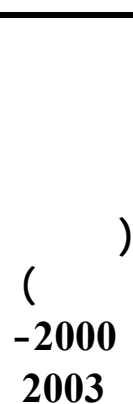 & 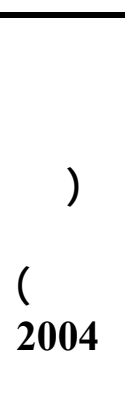 & الدط \\
\hline$\overline{-}$ & - & $\overline{-}$ & $\overline{-}$ & $\overline{-}$ & موربتانيا \\
\hline- & $\overline{-}$ & - & - & - & جزر الفمر \\
\hline - & - & - & - & - & جيبوقي \\
\hline 32 & $\overline{178.2}$ & 4484 & $\overline{2.6}$ & 281 & المتحليت \\
\hline 19 & 74.7 & 1613 & 4.9 & $\overline{-}$ & إسرائل \\
\hline 2 & $\overline{-}$ & 467 & $\overline{-}$ & 18 & إيرلن \\
\hline 2 & صفر & 341 & 0.7 & - & تركيا \\
\hline 18 & 92.4 & 3.108 & 2.5 & 266 & $\begin{array}{c}\text { مغالمة } \\
\text { DECD }\end{array}$ \\
\hline
\end{tabular}

على الباحثن بالاعتماد على:

الأم المتحة، قربر التنمية البشرية لهلم 2006، نيويورك 2006، بدلالة البيلذ لـ في الجدالل، 13، 16. - 20.

3 - يعد كل من العلم والقفانة قوتلن رئيستن تدعملن التغيير التاريخي وتحثلن التغيير على المستويت الثخصي مة والاجتماعية والمظماتية والوطنية والدولية . وآث ار التغيير القاني موجووة في كل مكان لكن التحنيل

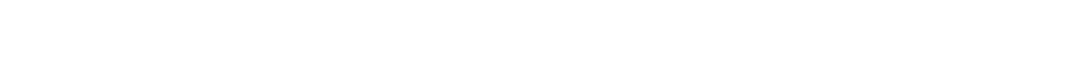

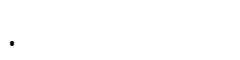

4 - تحقم طبيعة العلم والقانة أن تكون المساهمة المحلية لمراه| ضروريا

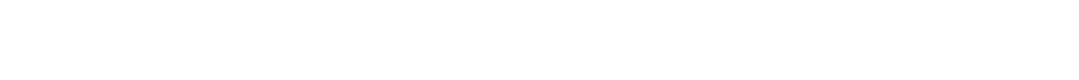


دون مل هذه التراطلت ظظل الأثر المضاعف المرتبط بيل لستثمار جديد صغيرا والعائدات الاقتصادية ضنئيلة.

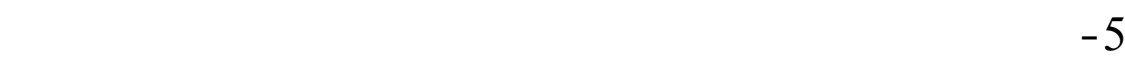

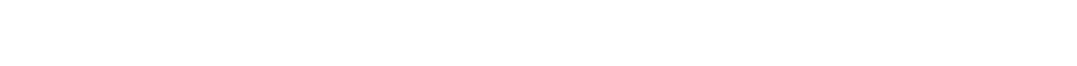

والقفانة. وإلا إذا كلفت الحكوملت قادرة على تبنىسيلي لت الت علمي ـة فاعلة.

6 - ولذا فلن مظومات العلم والقفانة هي الآليت التي تح ـول الق درات

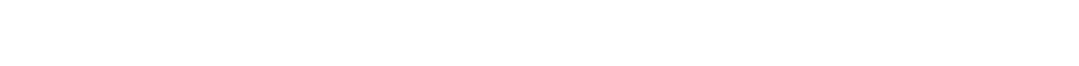

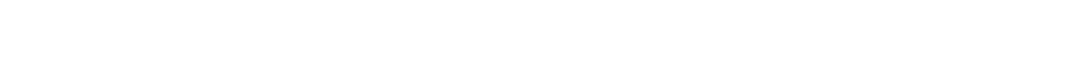

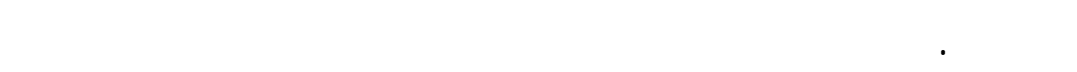

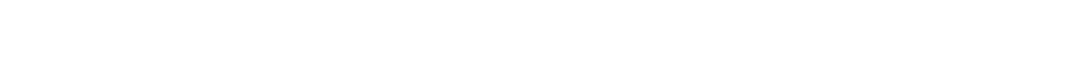

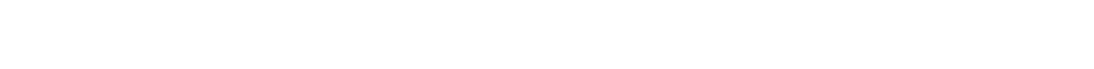

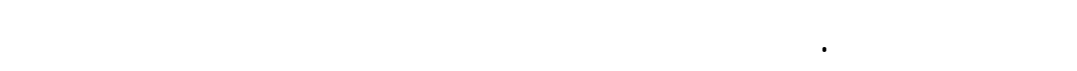
المظمة ولَككلمها.

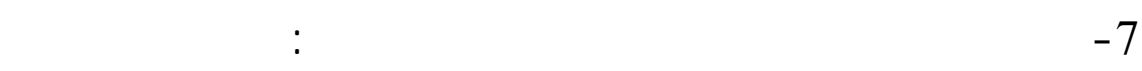

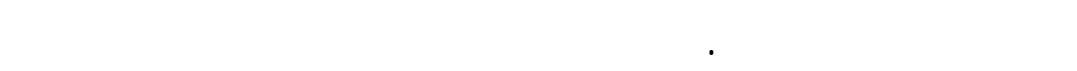

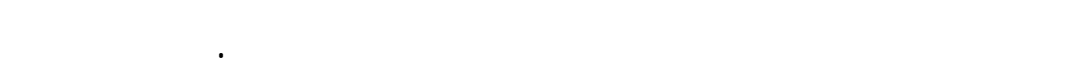

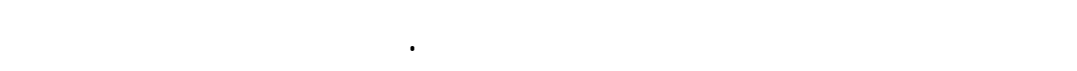

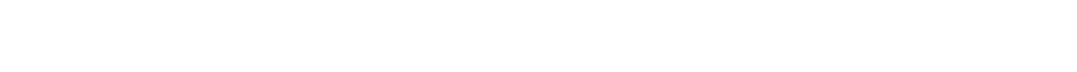

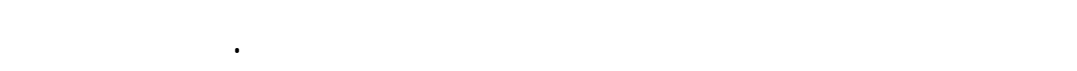

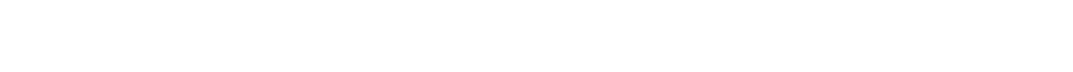

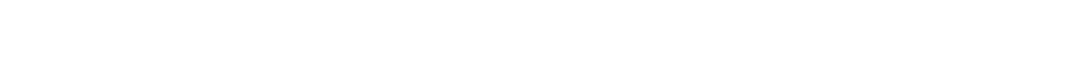
وخملت المعلوماتية والخملت المالية والجمعيت والقابك المهنية المنية. 
ومما يدعو إلى الإتغراب أن الصيرورات الطبيعية والمقاربة عادة لم

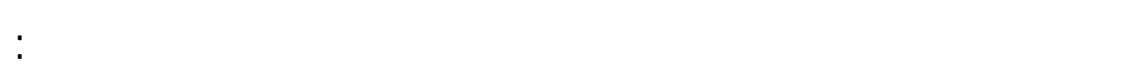
أ - ضضف الجمعيلت المهنية.

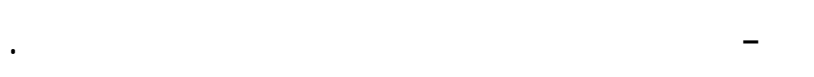
ج - فقدان الوعي البيئي الهنهي.

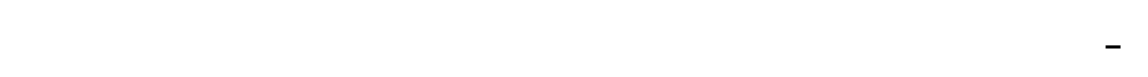
تمل جدي للقانة إلىشرككت محلية.

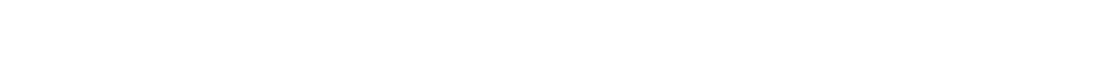

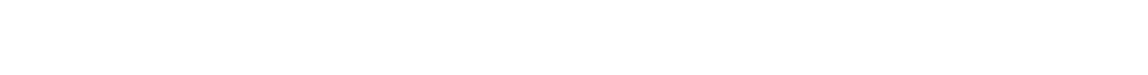
أي مصدر زمتاح.

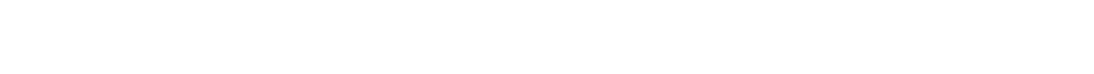

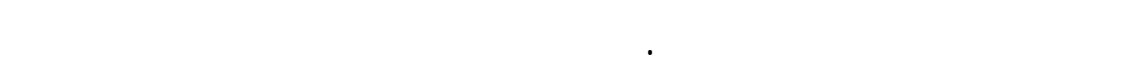

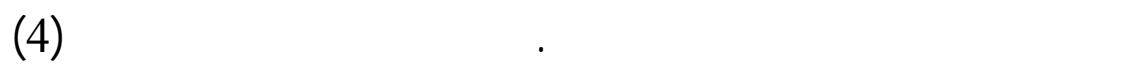

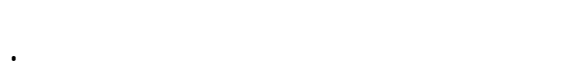

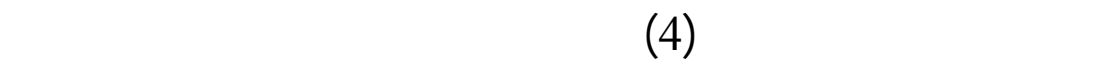
لمؤثررات القانة والمعلوماتية والاتصالات الرئيسة في الوطن العندئ العربي، التي تمثلت بهرلب المؤشررات التالية : • مسلب دليل الإبداع القني. • • مسلب دليل انتشار الاختراعات الحيثة. • • مسلب دليل النتشار الاختراعلت القديمة.

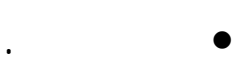
• عسلب دليل الانجاز القني.

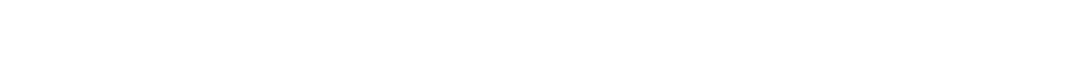

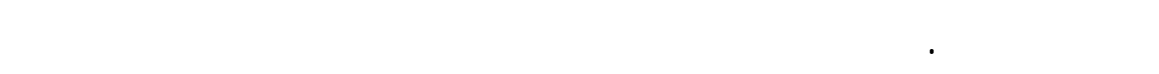


الاختراع ودللل بسوم الترخيص والملكية. ويمل دلبل الإب داع القذ ي المتوسط البسط للدليلين (**).

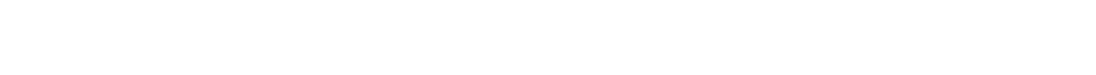

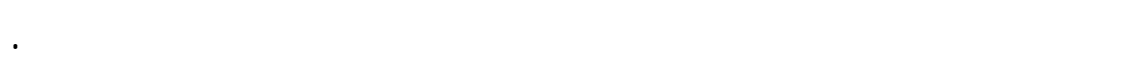

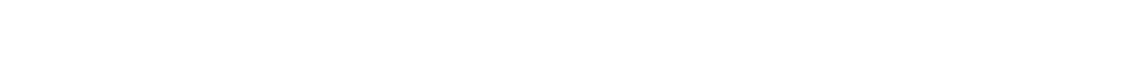

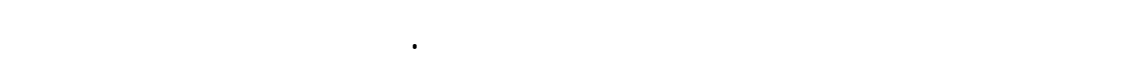

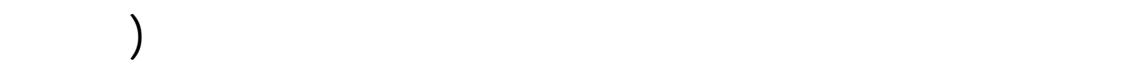

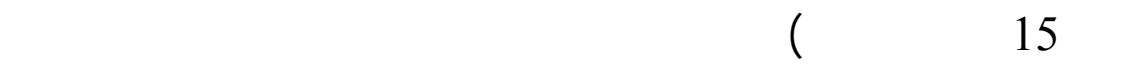

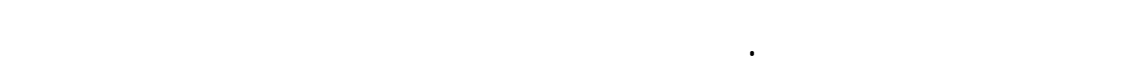

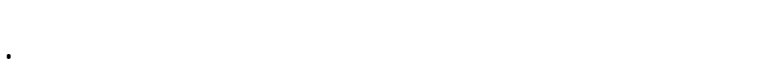

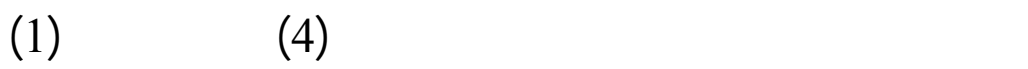
نستخلص مائئي :

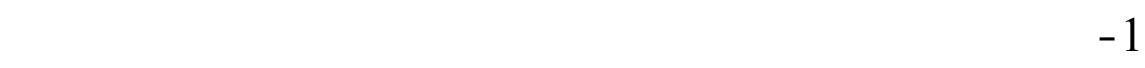

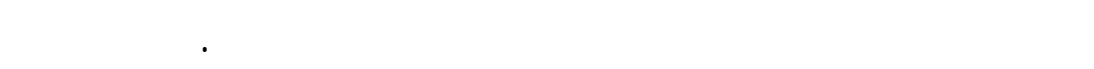

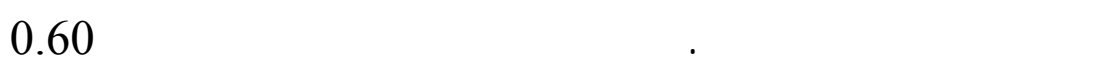

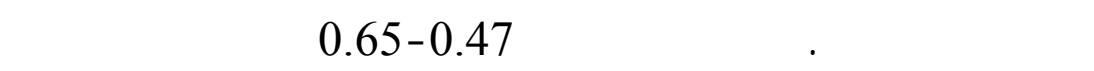
عملن والكويت على التوالي. في حين أن متوسط هذا الدئ الدليل في الدول

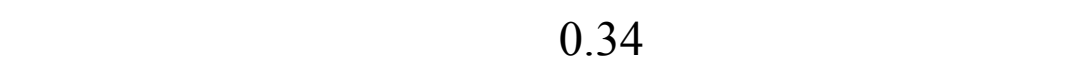

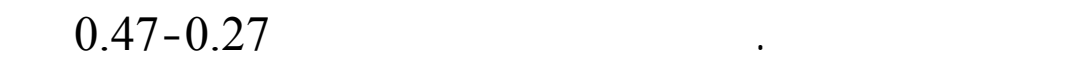
عليه الحل في كل من جيبوتي وسوريا على على الترتيب. 


\section{جرط (4)}

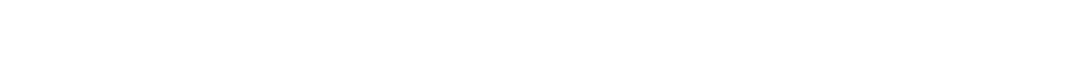

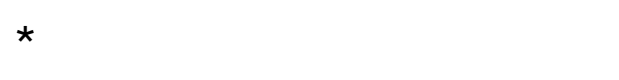

\begin{tabular}{|c|c|c|c|c|c|}
\hline 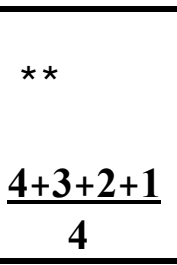 & التمليم & لالخت النشاعل & الخلب التشار & الإبدالع & الدط \\
\hline 0.61 & 0.71 & 0.92 & 0.22 & $\overline{-}$ & لأمارت \\
\hline 0.64 & 0.86 & 0.90 & 0.16 & - & البحرين \\
\hline 0.52 & 0.72 & 0.80 & 0.05 & $=$ & للمهويية \\
\hline 0.64 & 0.85 & 0.91 & 0.15 & - & قار \\
\hline 0.65 & 0.87 & 0.91 & 0.16 & - & الكوبت \\
\hline 0.47 & 0.77 & 0.74 & 0.07 & $=$ & عملن \\
\hline- & - & - & - & - & المرق \\
\hline 0.50 & 0.86 & 0.73 & 0.02 & - & ليبيا \\
\hline 0.44 & 0.71 & 0.58 & 0.02 & صفر & الجزائر \\
\hline 0.55 & 0.86 & 0.67 & 0.11 & $\overline{-}$ & لالرمن \\
\hline 0.57 & 0.86 & 0.72 & 0.12 & - & لبنلن \\
\hline 0.54 & 0.89 & 0.70 & 0.03 & - & فلسطين \\
\hline 0.47 & 0.74 & 0.64 & 0.03 & $=$ & سوربا \\
\hline 0.35 & 0.51 & 0.41 & 0.12 & - & اليمن \\
\hline 0.35 & 0.73 & 0.62 & 0.05 & 0.006 & مصر \\
\hline 0.29 & 0.53 & 0.32 & 0.02 & - & للسودلن \\
\hline 0.38 & 0.75 & 0.68 & 0.09 & 0.006 & تونس \\
\hline 0.33 & 0.45 & 0.61 & 0.16 & 0.001 & المغرب \\
\hline 0.30 & 0.49 & 0.39 & 0.002 & - & موربتلنيا \\
\hline 0.23 & 0.53 & 0.15 & 0.01 & - & جزر \\
\hline 0.27 & 0.52 & 0.27 & 0.005 & $\overline{-}$ & جيبوقي \\
\hline
\end{tabular}




\begin{tabular}{|c|c|c|c|c|c|}
\hline 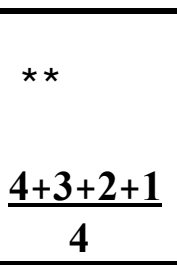 & التعليم & لالخت النتشار & الختل الختشار & الإبدالع & الدط \\
\hline 0.75 & 0.97 & 0.92 & 0.67 & 0.44 & المتحية \\
\hline 0.68 & 0.95 & 0.90 & 0.46 & 0.15 & إعرائل \\
\hline 0.34 & 0.75 & 0.53 & 0.07 & 0.004 & إيرل \\
\hline 0.56 & 0.81 & 0.75 & 0.11 & - & تركيا \\
\hline 0.65 & 0.95 & 0.89 & 0.46 & 0.29 & $\begin{array}{r}\text { مة مECD } \\
\text { DECD }\end{array}$ \\
\hline
\end{tabular}

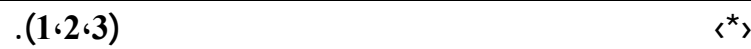

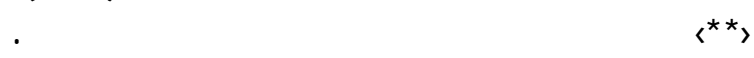

بيد أن هذه الصورة تتغير تملما بالأهداف المقارية كالولايت المتح ـة الأمريكية ومجموعة دول مظمة التعاون الاقتصادي والتنمية ( O E C و (D)

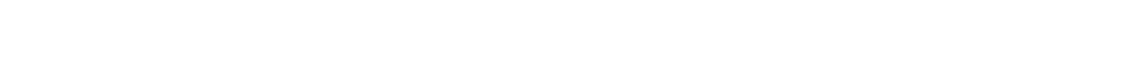

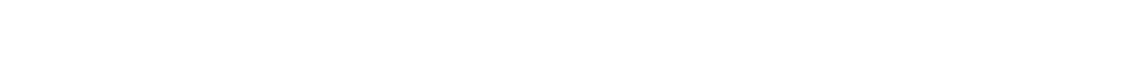

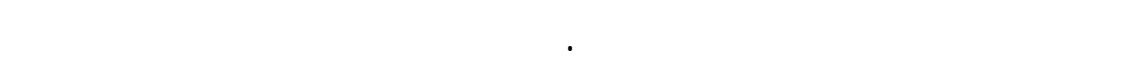

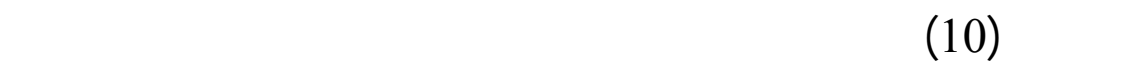

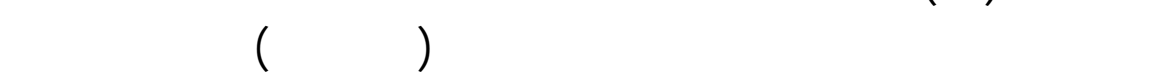
والكيمياويت الناعمة ومواد الصيدلة والأعمل الفنية وصياغة المجنين المجوهرات

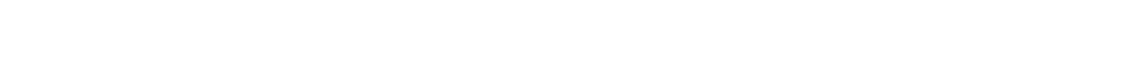

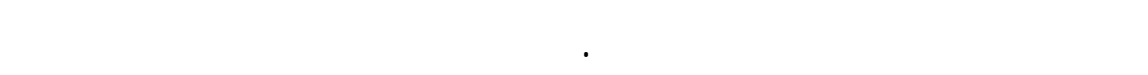

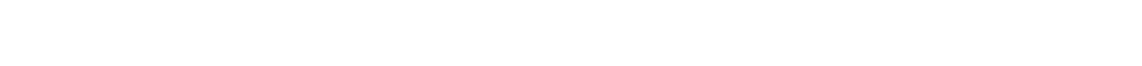
التعليم ونوعية البف التحتية الفعلية. فلمتلك الموارد المعني ـة لايحم مي 


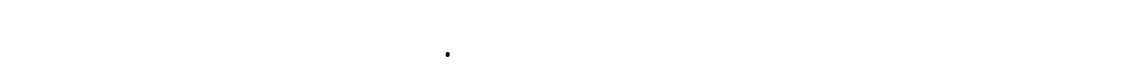

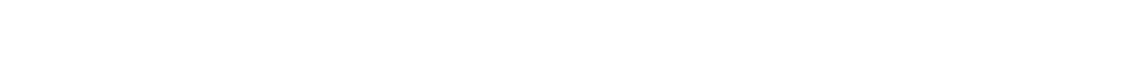

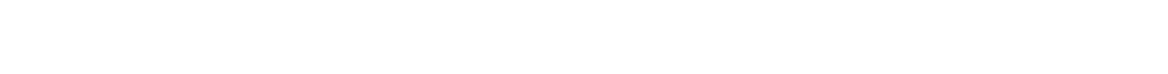

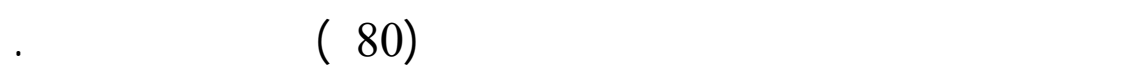

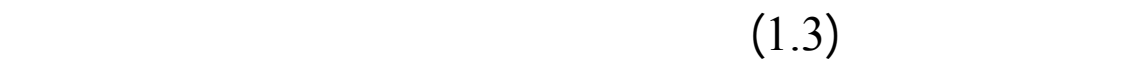

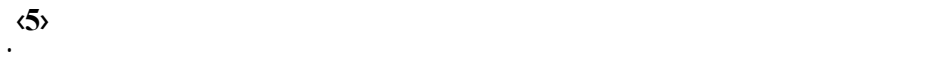

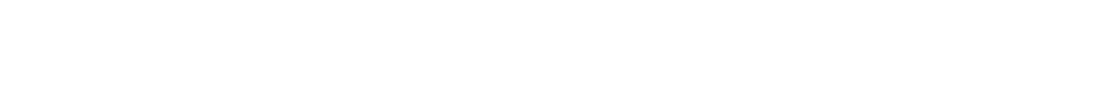

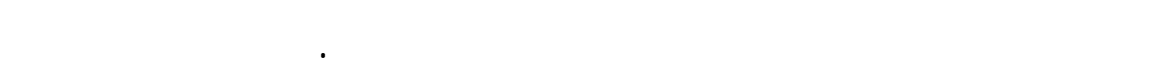

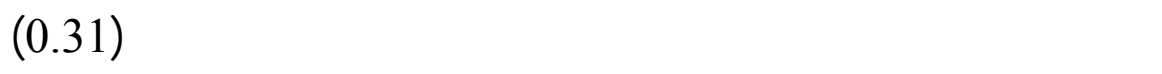

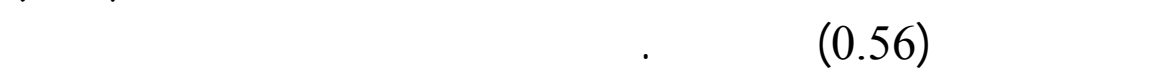

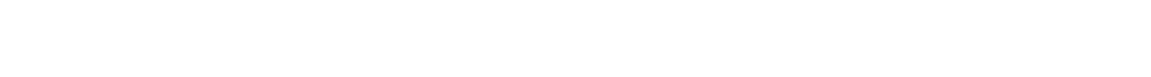
مقارنة بالدول الصناعية.

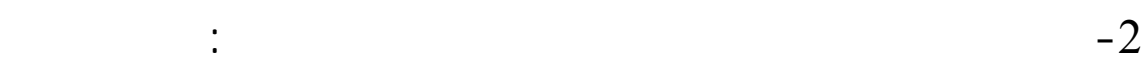

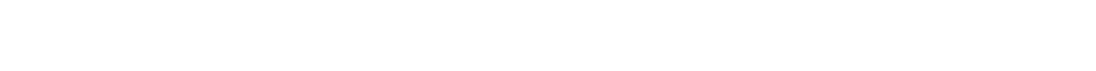

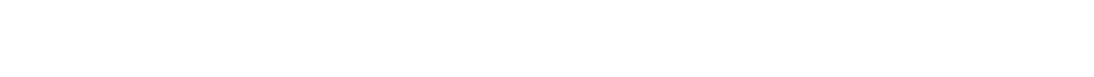

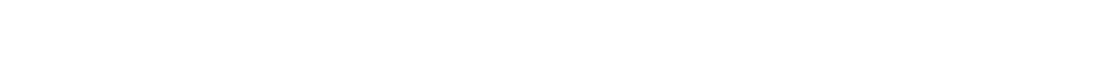

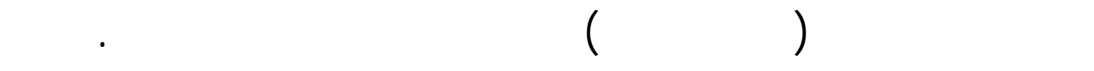

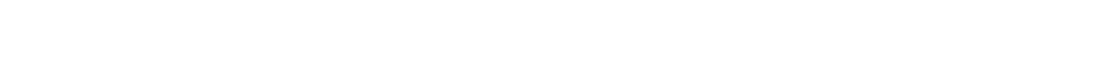

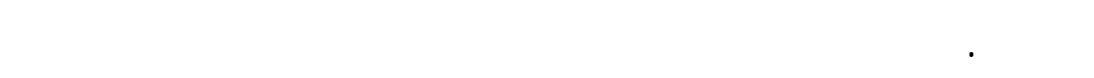

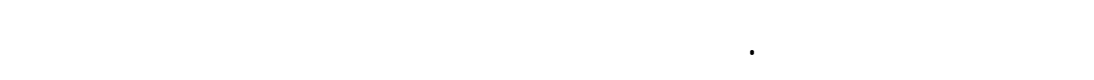

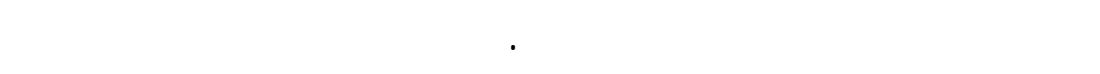

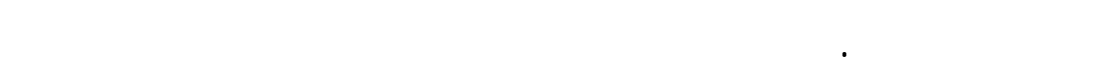

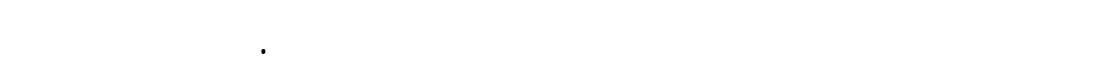

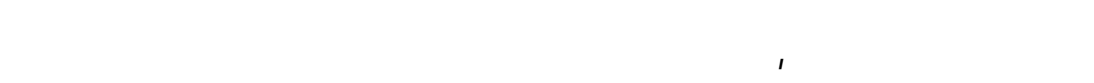
الهيكلي وتحقيق التنافسية. 
درلست إقليمية 5 (11)
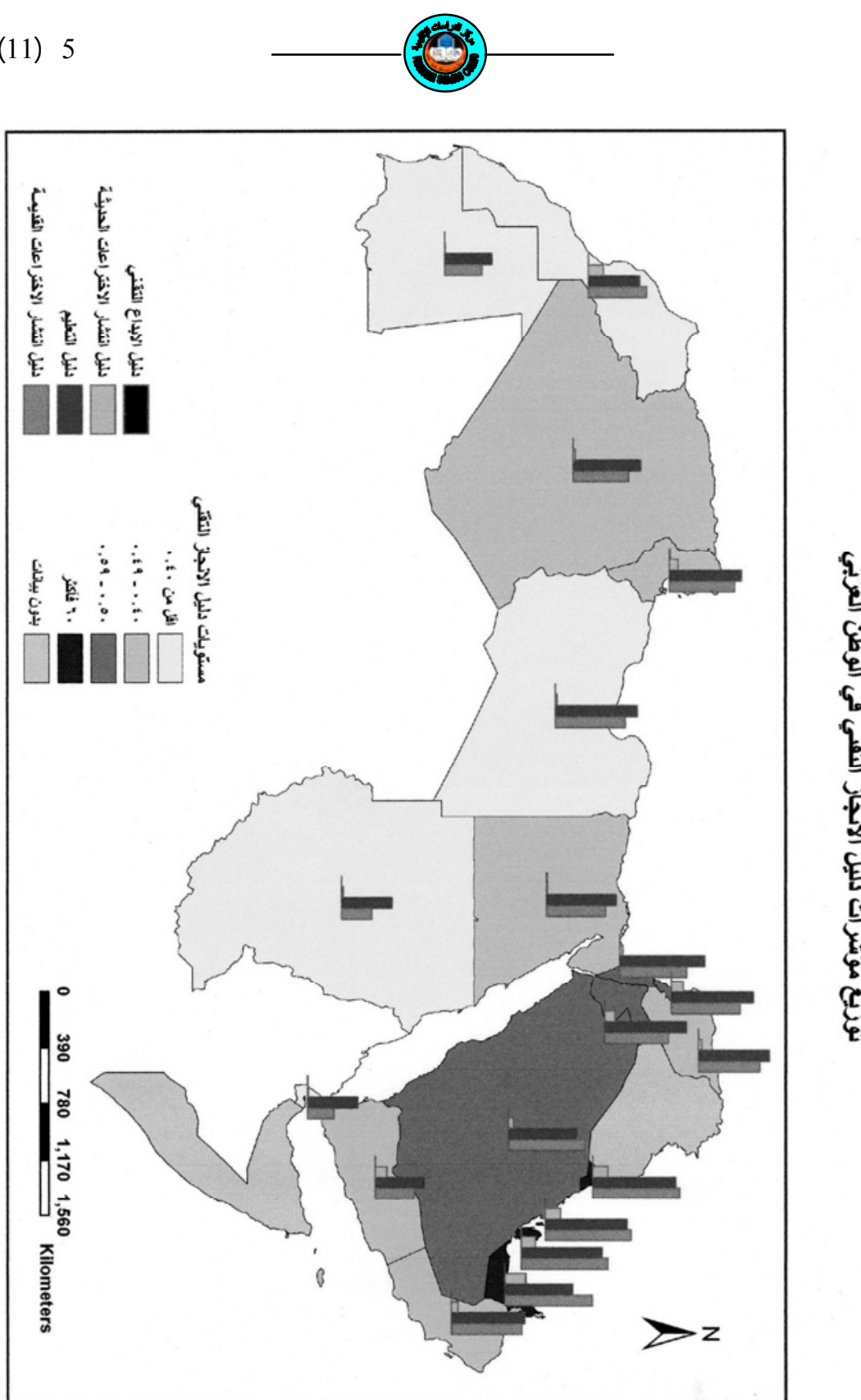

है 
ويقف الظلم التعليهي في مقلمة الإبهالم في التنمية البثرية ومن ثم بذ اءاء

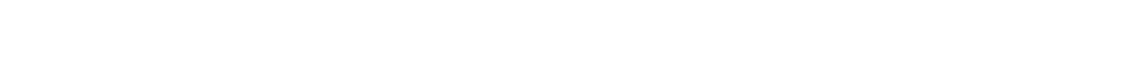

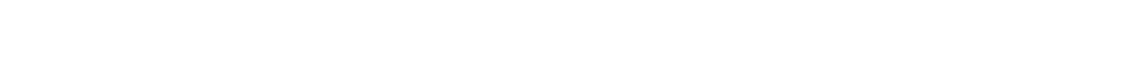

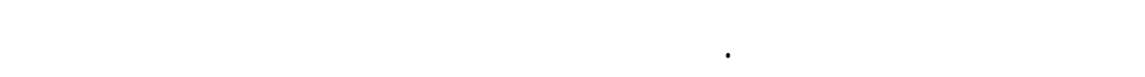
لتكوين رلأس المل البشري والرصيد القاني الملائ للنهضة والظوير.

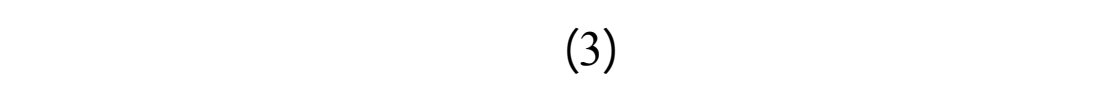

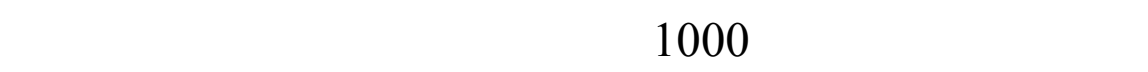

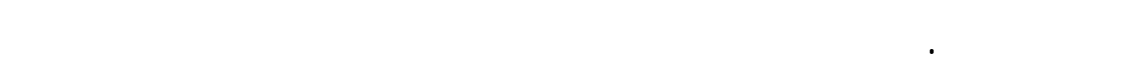

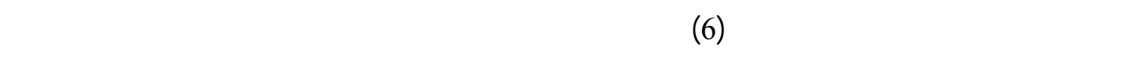
الانترنت. والصورة ذاتها تتنكرر في مسألة لستخدلم الهوافف كما رأينا

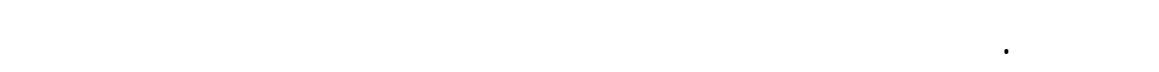

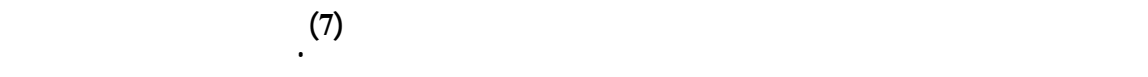

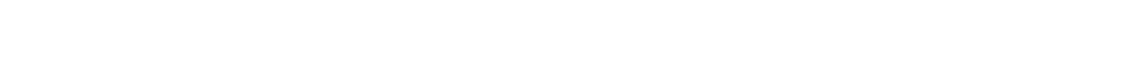

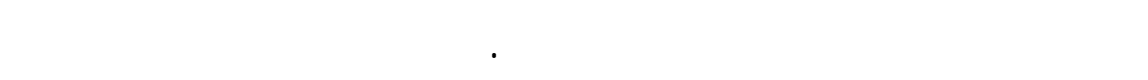

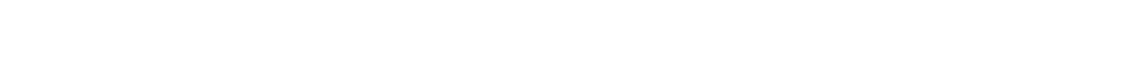

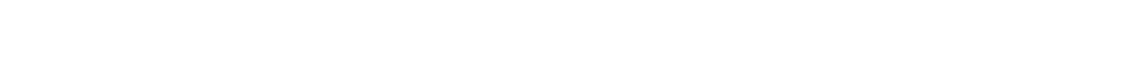

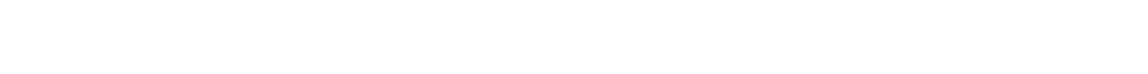
الضعف في جسم هذه الدولطقا لمفاهيم الجغرافيا للسيلسية.

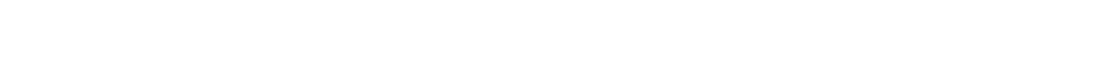

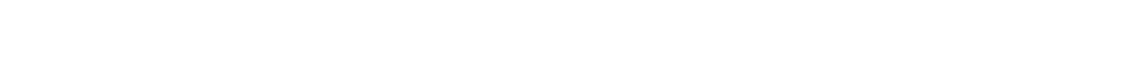

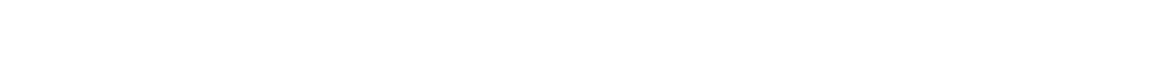

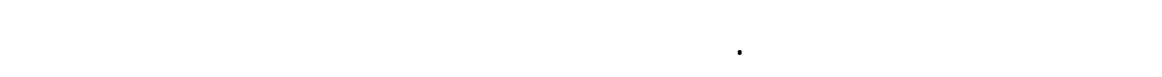

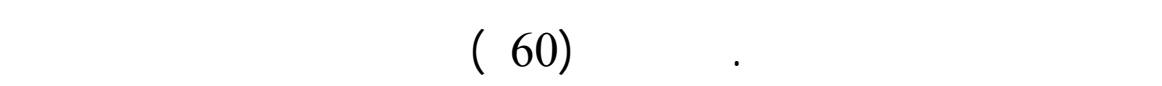


يقيمون في أمريكا الشمالية وانسكانها لايمثلون (5٪) منسكان الع الم.

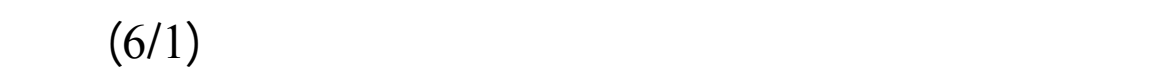

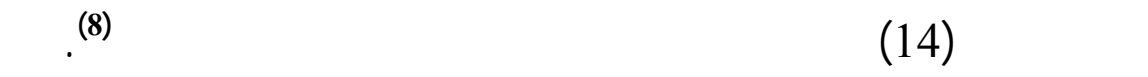

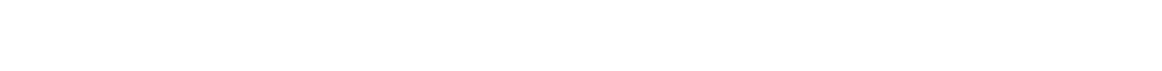

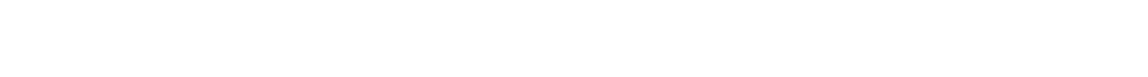

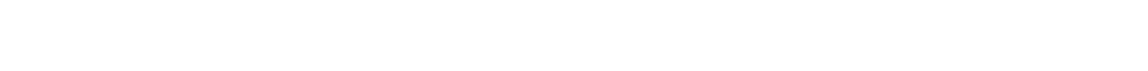

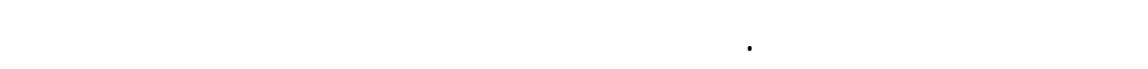

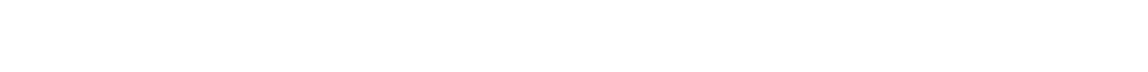

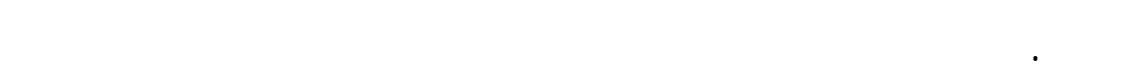

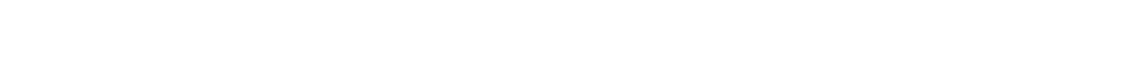

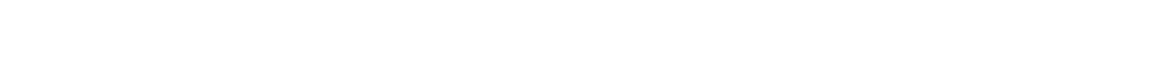

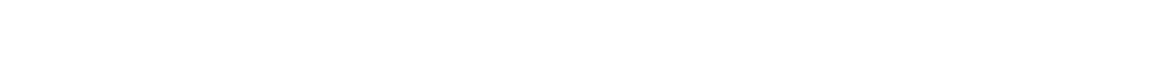
المظوملت العلم والقانة (9).

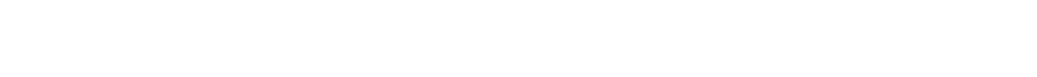

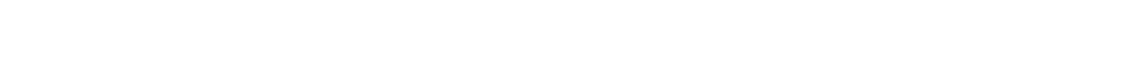

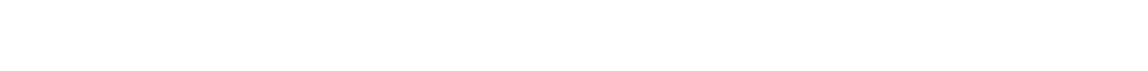

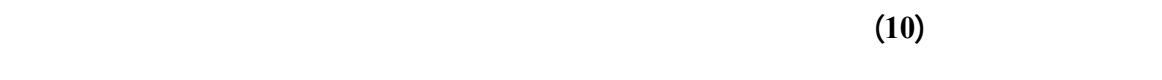

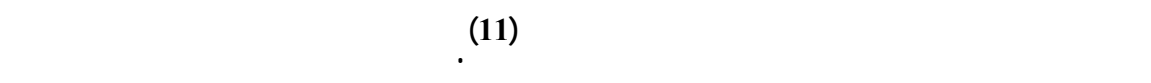

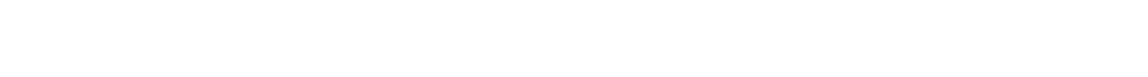

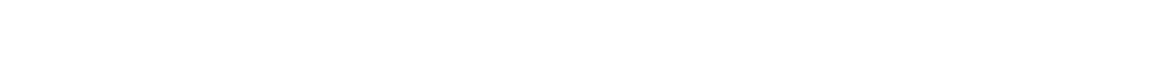
الأفطار (12). ناهيك عن طبيل الحيعة الحكومات وسيطرة البيروقرلطية الحكومية وسيلساتها المناوئة لبناء المؤسست. 


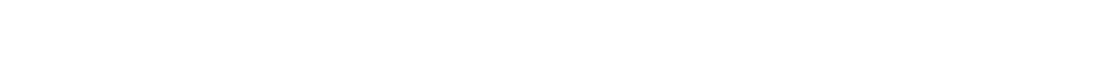

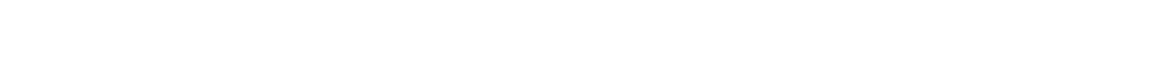

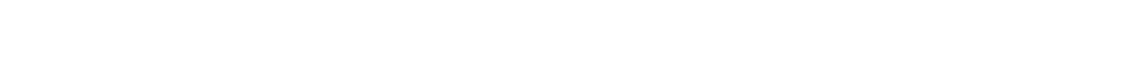

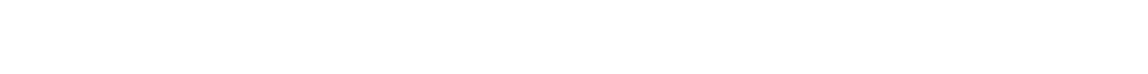

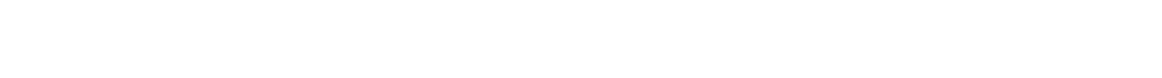

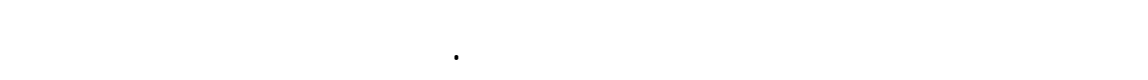

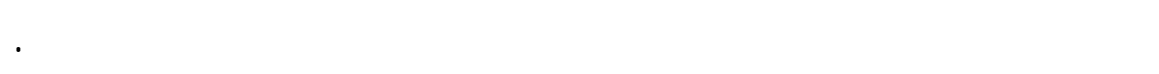

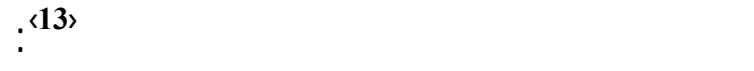
1 - نسبة الإفاق على البهث العلمي من الناتج المحلي الإنمالي.

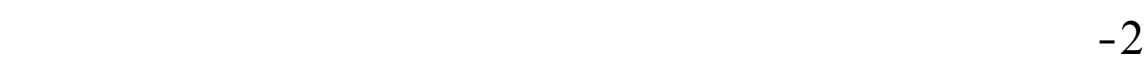

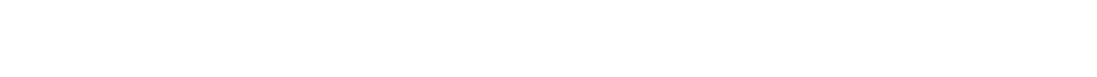
القاني. 3 - نسبة الإفلق على التعليم إلى إجمالي الإفلقاق.

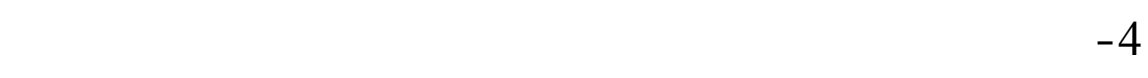
من لجمالي الإففاق على التعليم العالي.

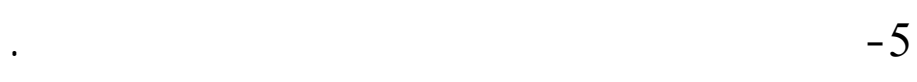
6 - صافي المدفوعت القانية المرتبطة ببراءات الاختراع المبحاع وحق المعرفة والعلمات التجارية وحقوق الطبع والمعونات. 7 - مدى الاعتماد على الأجانب في مجالات البحتية البحات والمهنية المهنية والتدريب. 8 - نسبة التصنبع المحلي وغيرها. 


\section{ثالثاا: الستنتاجلت ( النحيلت والفرص المنالة ).}

حاطل ما تقدم.

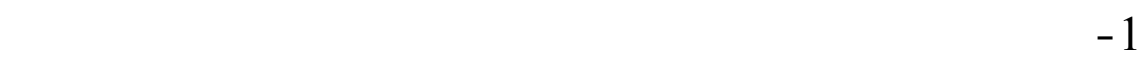

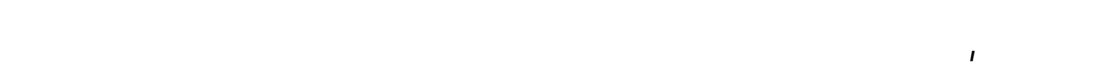

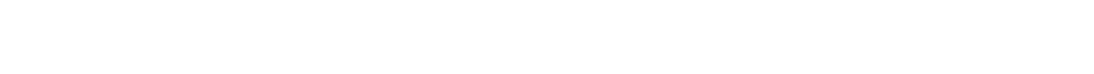

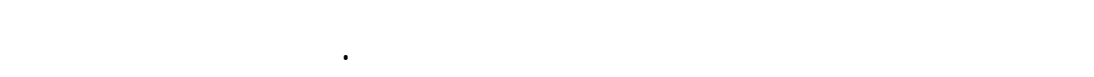
دور واضخ لهذه العناصر في الوطن العربي.

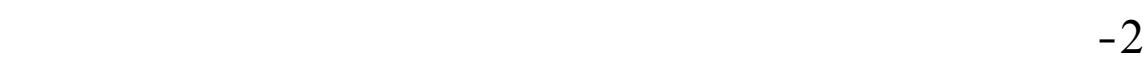

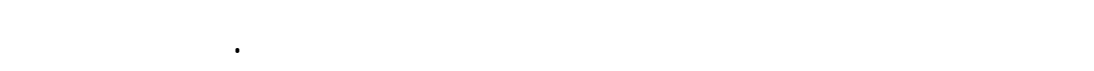

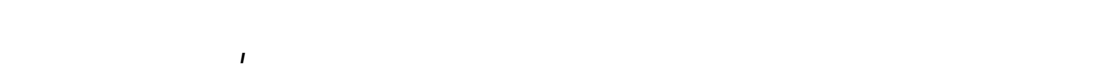

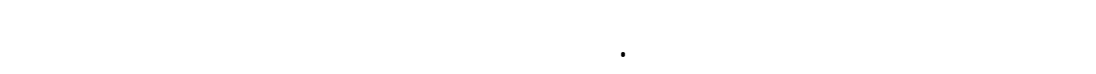

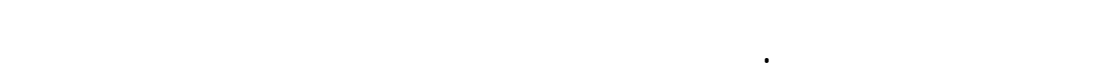
اللسيلسة الاقتصادية.

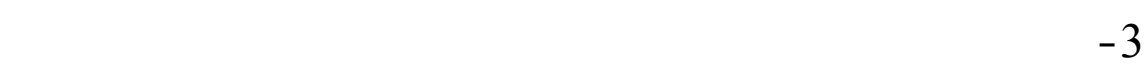

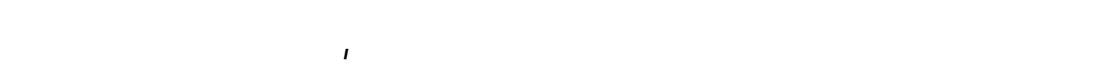
دون لخرى , فضلا عن عدم توافر مؤشررات كلفية طقة المات لما هو عليه

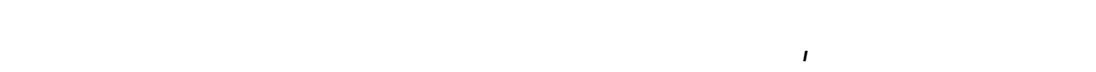

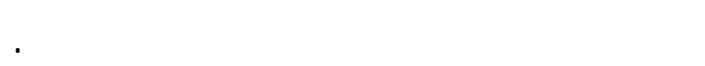

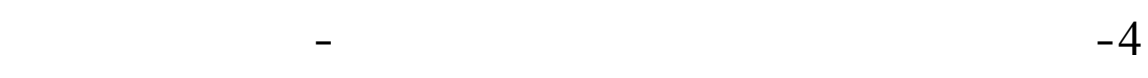

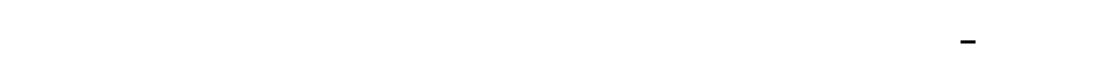

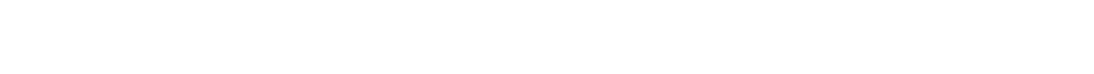
الأفظار العربية. 
5 - لم تثمرسيلست التعليم الحالية في ظلل واقعها هيكلاًا ومضمونابشبهيء

$$
\text { فاعل في هذا المجل. }
$$

6 - هنك فجوة حضارية مقفاقمة تظط ـوي عل مه فج ـوات المعلوماتي ــة

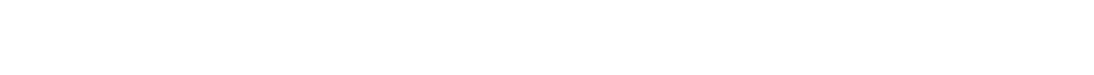

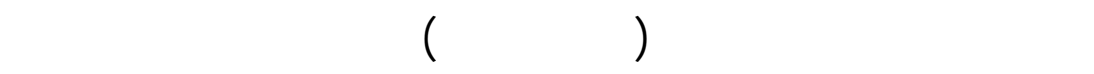

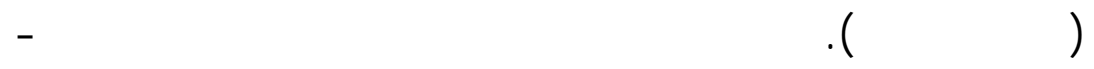

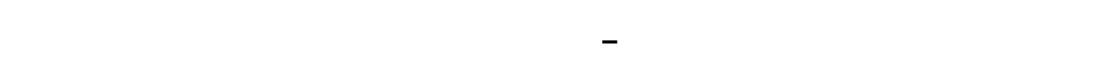

$$
\text { التنفر والتجزئة. }
$$

7 - ضآلة نصيب الفردمن الناتج المحلي الإجمالي في الوطن العربي مما

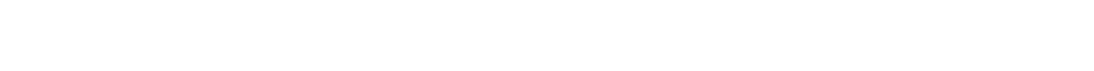

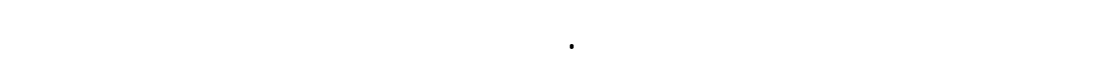

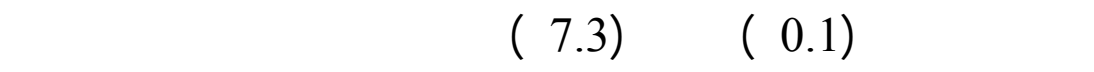

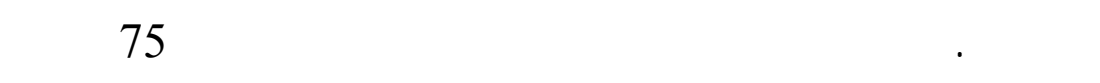

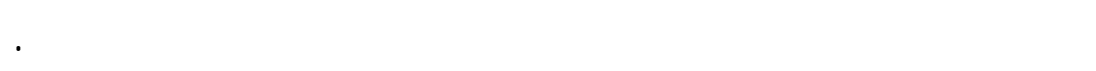

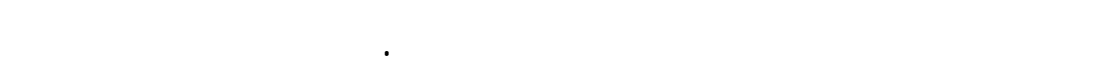

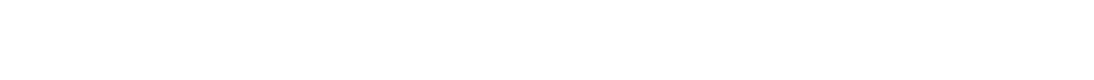

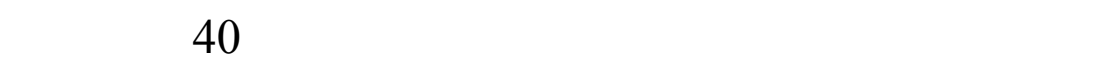

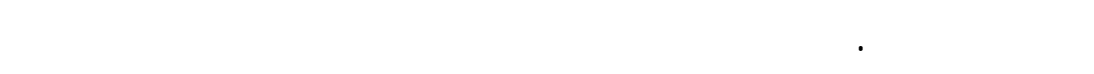

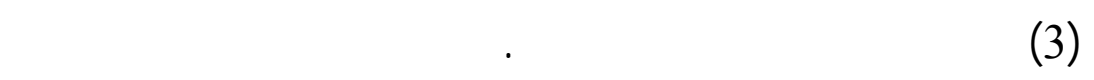

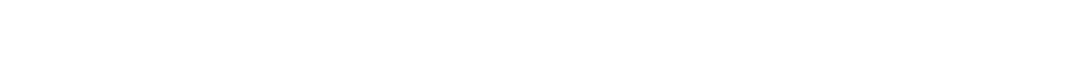

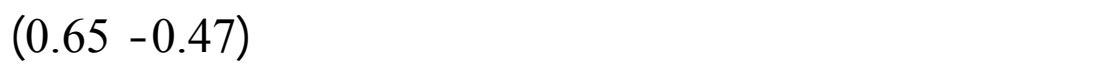

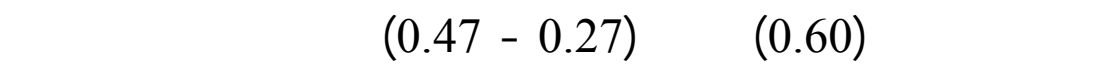
بمتوطط (0.34). 


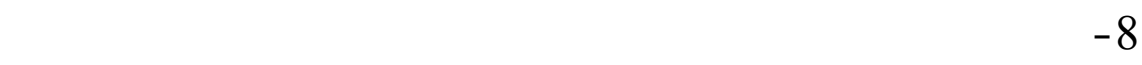
سيلست العلم والقانة هي المسؤولة عن هذا الواقع في الوطن العربي

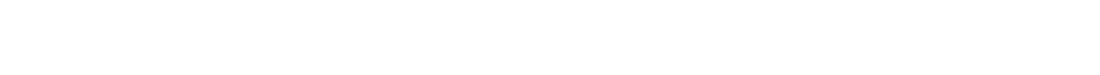
العلمية . فالود مققود بين البلمث العلهي وصانع القرار في الدولة ـ مما

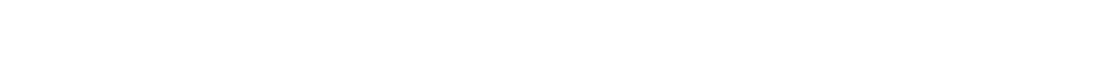
لمكلم اللسطرة الأجنبية. وإزاء ما ققدم فلن هنك العديد من التحديت تولجه فاعلية هذا العنصر

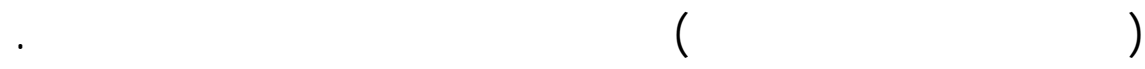

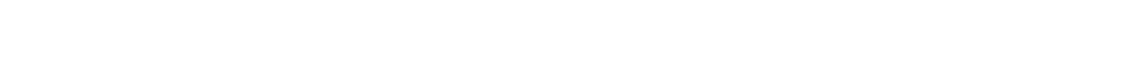

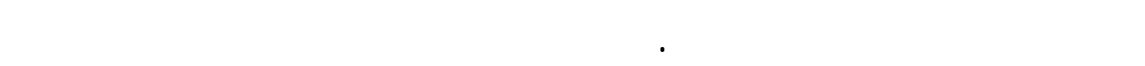

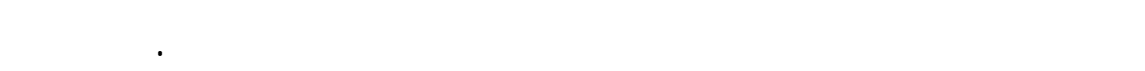

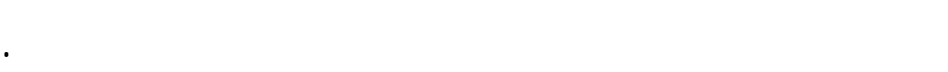

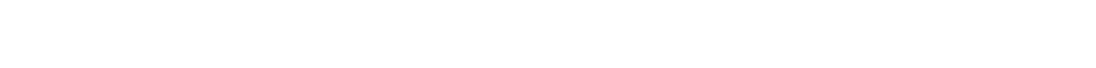

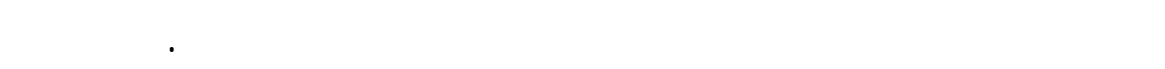

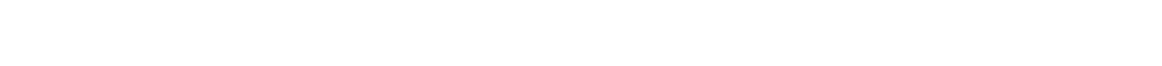

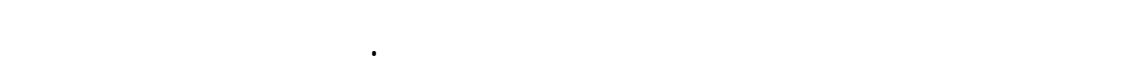

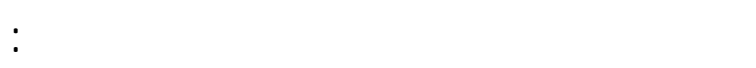

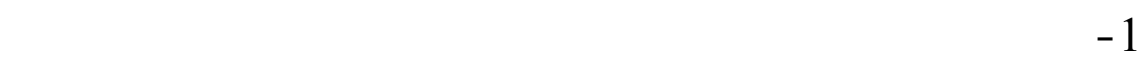

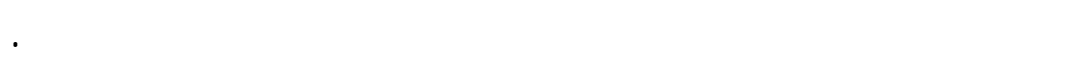

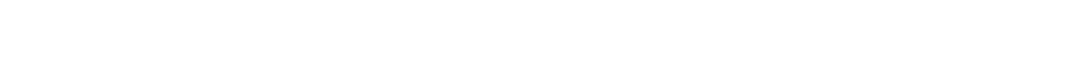

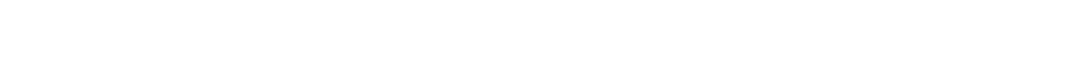




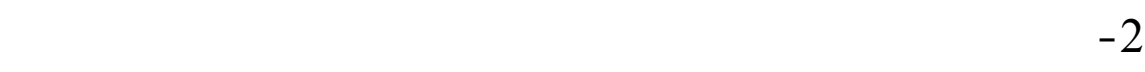

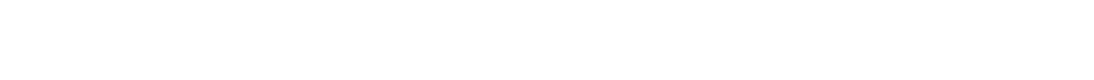

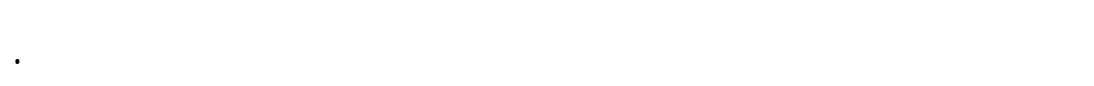

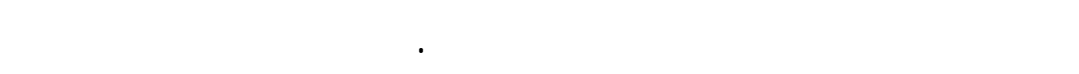
هذه الميلسة المنشودة: أ - تحديد أهداف لستراتيجية قابلة التحقيق على مستوى التعليم.

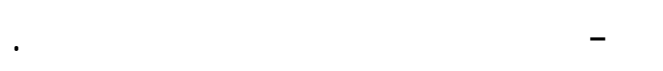
ج - العل على زيادة الروابط بين المؤسست التعليمية والاقتص الية والالجتماعية. د - تألمين الحصول على الحية التعليم لكافة أبناء المجتمع. هـ ـ - الاهتملم بالتعليم المستمر.

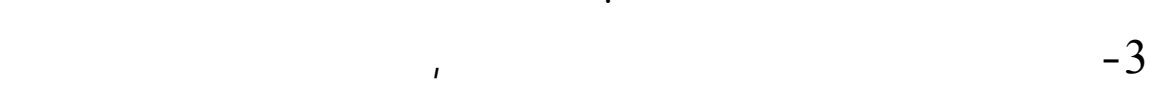

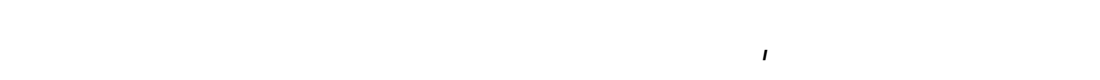

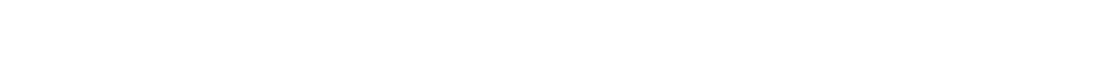

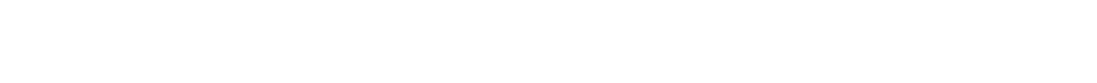
وعليه فلن مظومات العلم والقانة هي الآليت التي تححل القدرات

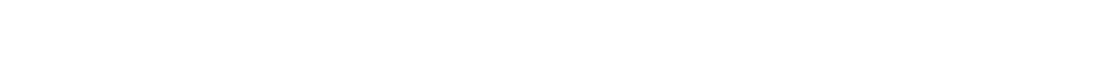

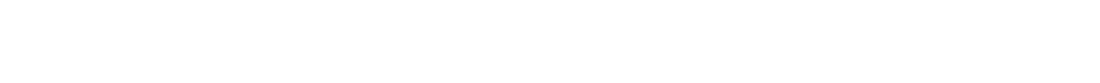
في الجغرافيا للسيلسية.

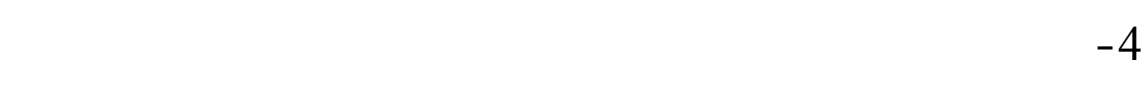

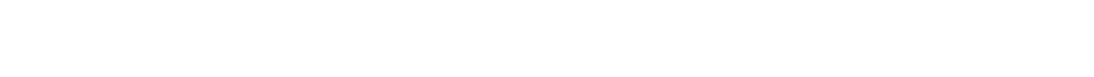

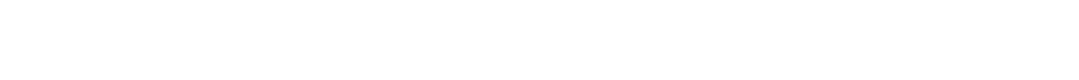
الفجوة الحضارية من خلل العائدات الاقتصادية. 
ولخي -رأ إن ما قـ حم لايمكن أن يؤتق ثماراطيبة إلامن خلال: تبني

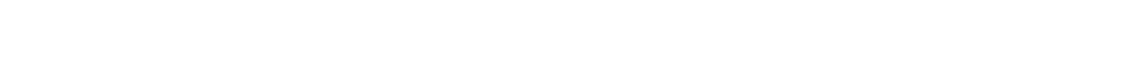

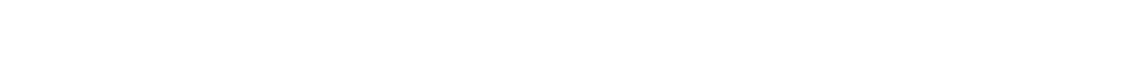

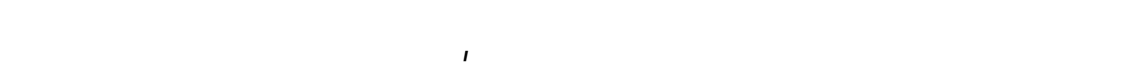

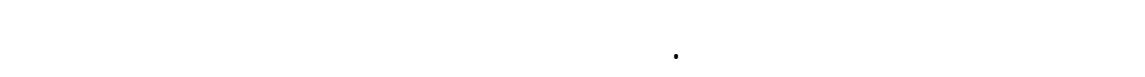

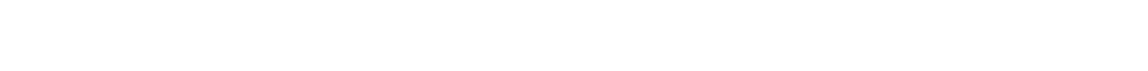
الصناعي الحالي يصح الظلم التعليمي المورد المسترالتيجي الأكثر أهمية.

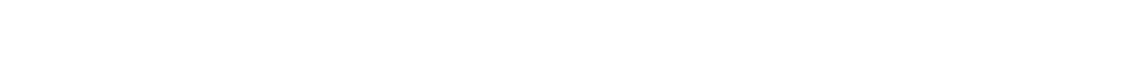
الحكومات الإلكترونية في الأهداف والألساليب. 


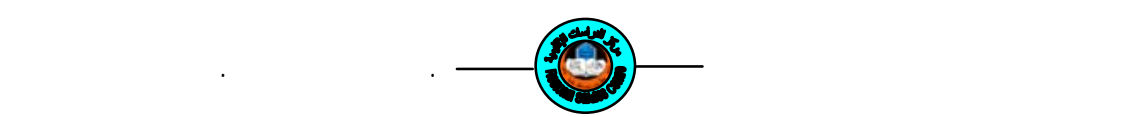

\title{
Geopolitics of Information and Communication Culture in The Arab Homeland: Challenges and Available Chances.
}

\author{
Dr. Ahmed Hamed Al-Obaydi \\ Assist Prof, Geagraphy \\ Department, Educatian \\ Callege, Masul Uniu.
}
Prof Dr. Mohammed Azher Al- Sammak Geagraphy Department, Educatiau Callege, Masul Uniu.

\begin{abstract}
This research aims at studying the Geopolitics of Information and Communication Culture in The Arab Homeland. This study hypothesizes that the current situation of information and communication is not that promising, since its minor role in enhancing the strength of this region in the political map according to the analysis of the available chances in facing all the challenges. This research studies

I. The current state of information and communication culture. II. The quantity measuring of technical and information achievement: Guides for technical achievements, patents, Guides for new and old inventions and human creativity III. Conclusions (challenges and potential chances).

The search came up with some conclusions, one of these is the necessity of adopting a unified Arabic strategy in the field of information and communication through special national systems of culture and communication. In addition to that the work towards the rise of the Arab nation is to move side by side with "Information Revolution" and "Globalization".
\end{abstract}


الهولشن والمصالر

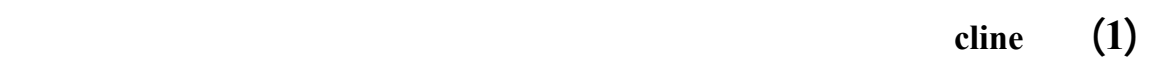

$\mathbf{P p}=\mathbf{C}+\mathbf{E}+\mathbf{M}+(\mathbf{S}+\mathbf{W})$

$\mathrm{C}=$ Critical Mass

$\mathbf{E}=$ Economic Capability

M = Military Capability

S = Strategic Purpose

W $=$ Will to purpose national strategy

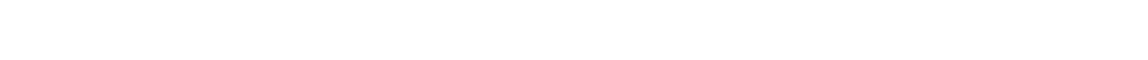

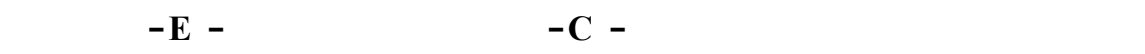

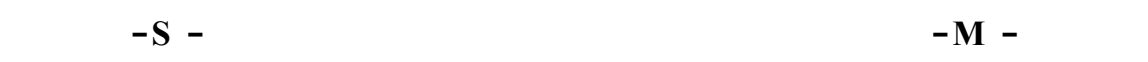

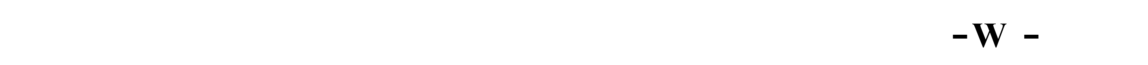
عناdرقوة الدولة.

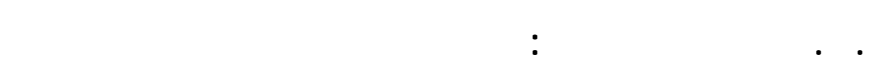

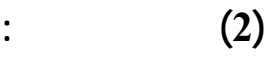

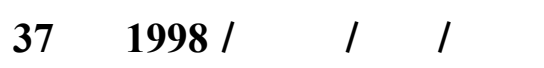

و أ. د. محمد أزهر اللسمك: الأرن الجغرفيا للسيلسية بمظلور القرن

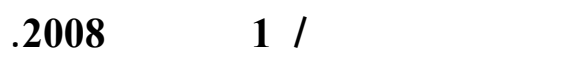

(3) يظار:طالرقشرف يونس ومحمد اللعامنة. الككومة الاكترونية وقلبيقاتها فلي

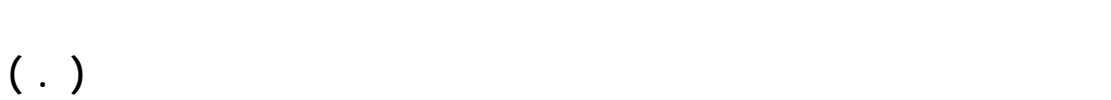

$$
\text { .117- } 1 \text { ص } 2004
$$

(*) مقامة (2.D.C.

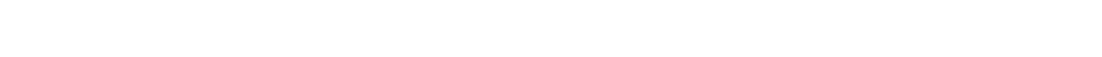

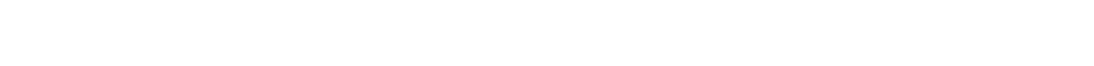

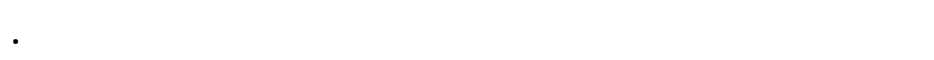

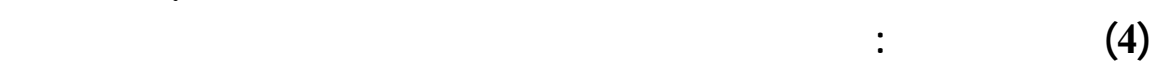

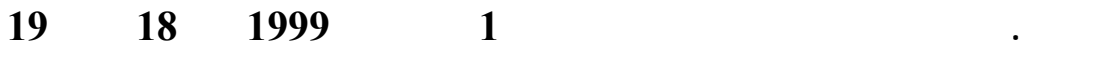

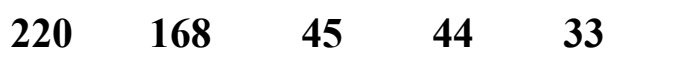




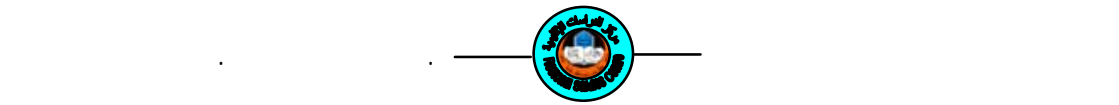

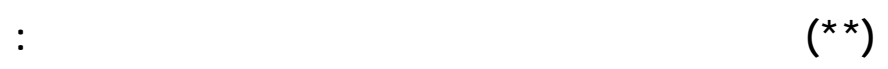

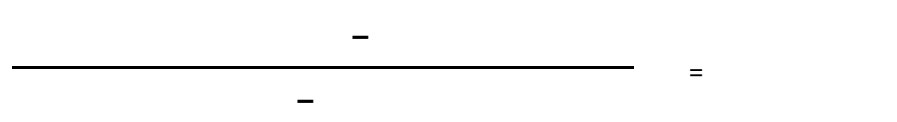

وبم التعبير عن الأداء لل مؤشر جيمة تسرالهح من صفر إل م ولح د. وب شم

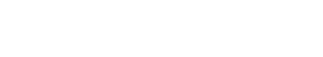

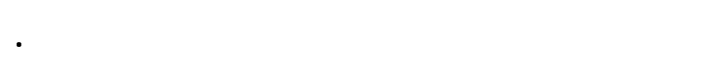

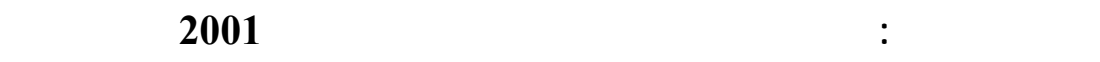

$$
\text { 264. }
$$

(5) ألملولن زخلان، مصدرسلاق، ص255 250 -256.

(6) يظار:كورل هبرو، التصل والثغير الجتماعي في الول النامية، ترجمة فحمد

ناجي جونهر كورن

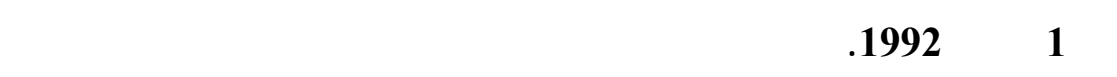

تكنولوجيلت المعلومات

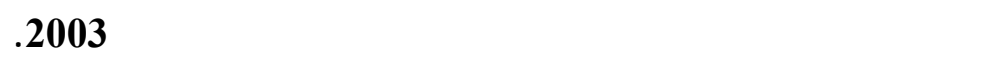

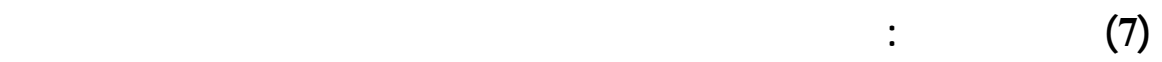

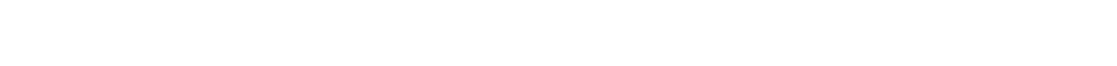

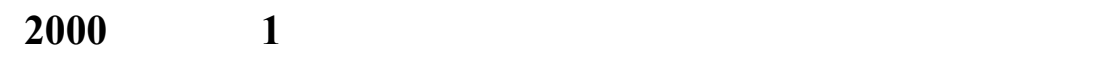

$$
\text { ص ص }
$$

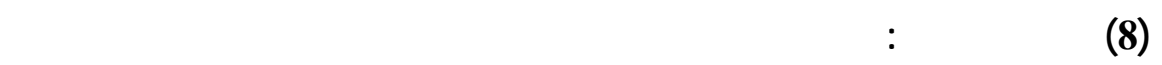

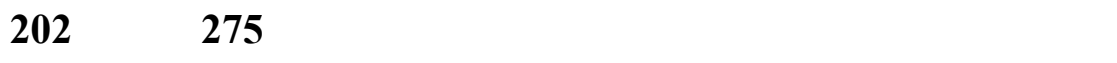

ص 58 -79، وبطار الفالصل أليضا.

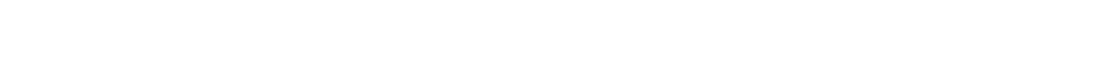

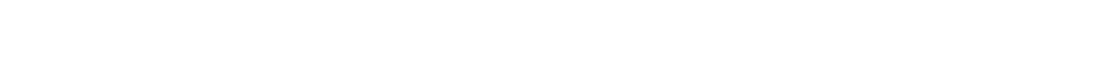

232 بيروت 1998، صفيرة ص ص 8 -29

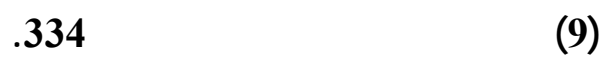

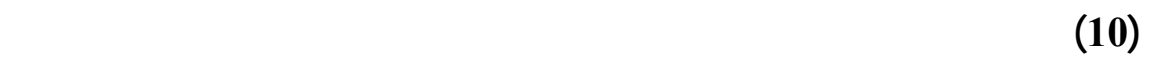

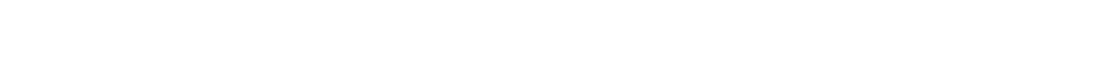

14، جامعة الموصد ل و 2007، ص ص 5 -189. 
درلست إقليمية 5 (11)

(11) الفاصل عن العولمة وعلافتها بموضوع هذا البهث يظلر : ملاح المين

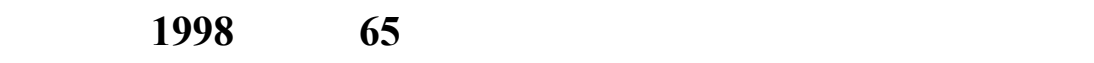

(12) للوقف عل آلية تعزبزقرات القلنة العربية يظار : ألملول زطلان، كيف

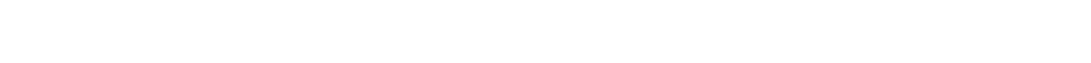

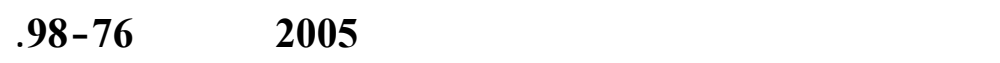

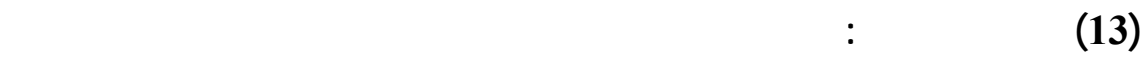

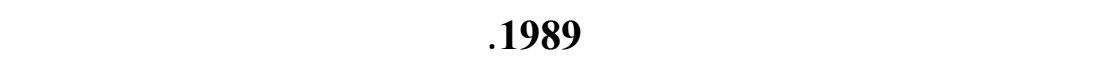

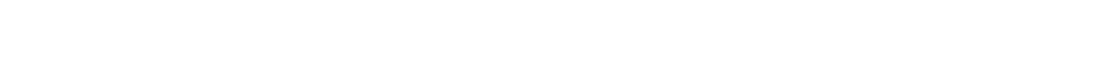

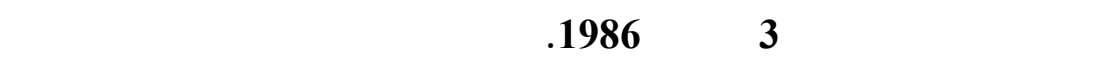

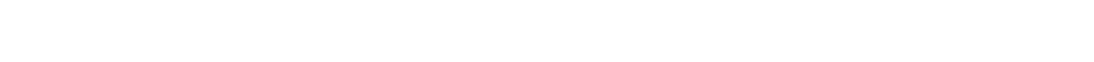
العري، مركز مرلسلت الوحة العربية، ص ص العر 82 -95. 